\title{
Chiropractic and Christianity: The Power of Pain to Adjust Cultural Alignments
}

\author{
Candy Gunther Brown
}

$\mathrm{D}$ ANIEL David Palmer (1845-1913) reputedly "discovered" chiropractic in 1895 when he performed the first "adjustment," using spinal manipulation to restore hearing to an African American janitor named Harvey Lillard. ${ }^{1}$ Relegated to the fringes of American medical and religious orthodoxy for most of the twentieth century in part because of its metaphysical philosophy, today chiropractic is mainstream: its offices can be found in strip malls; medical insurance plans cover adjustments; and, in a dramatic readjustment of traditional cultural alignments, conservative Christians embrace chiropractic as a God-given method of pain relief.

Most Americans have forgotten that previously many people perceived a conflict between chiropractic and Christianity, and that the mainstreaming of chiropractic is a recent development that requires explanation. The significant analytical question asks how a practice once widely classified as medically and religiously illegitimate came to be reclassified as legitimate by many Americans, perhaps most surprisingly by evangelical and Charismatic Christians. ${ }^{2}$ The convergence of chiropractic and Christianity is one manifestation of what historian Catherine Albanese has called the "combinativeness" of American religion. ${ }^{3}$ This essay presents a case study of "metaphysical" and "evangelical" religion growing up together and intermingling in frequently unacknowledged

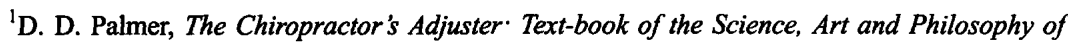
Chiropractic for Students and Practitioners (Portland, Or.: Portland Printing House, 1910), 18; Gordon Linhart, "Selling The 'Big Idea': B. J. Palmer Ushers in the Golden Age, 1906-1920," Chiropractic History: The Archives and Journal of the Association for the History of Chiropractic 8, no. 2 (1988): 25.

${ }^{2}$ For the rise of alternative healing and parallels between other alternatives and chiropractic, see Robert C. Fuller, Alternative Medicine and American Religious Life (New York: Oxford University Press, 1989), 55-60; James C. Whorton, Nature Cures: The History of Alternative Medicine in America (New York: Oxford University Press, 2002), 258, 277; Catherine L. Albanese, A Republic of Mind and Spirit: A Cultural History of American Metaphysical Religion (New Haven, Conn.: Yale University Press, 2007), 508-9; J. Stuart Moore, Chiropractic in America The History of a Medical Alternative (Baltimore: Johns Hopkins University Press, 1993), 205.

${ }^{3}$ Albanese, Republic of Mind and Spirit, 149.

Candy Gunther Brown is Associate Professor of Religious Studies at Indiana University. 
ways. ${ }^{4}$ As such, it responds to Albanese's call for a "historiography of connection" among overlapping religious cultures. ${ }^{5}$ Although efforts to transplant chiropractic overseas produced weak offshoots, chiropractic has thrived in the American religious soil. ${ }^{6}$ Cultivating a "therapeutic" culture that privileges practical fulfillment of individual needs over religious or medical orthodoxy, Americans in need of healing often experiment with therapies derived from competing philosophies, culling select techniques from the theoretical premises that contextualize those techniques. ${ }^{7}$ In what scholars term lived religious practices, people select, negotiate, and create from available alternatives as they confront life's complexities, particularly when fundamental matters such as health, illness, and healing are at stake. ${ }^{8}$

The case of chiropractic has far-reaching implications for understanding the interconnectedness of scientific, metaphysical, and evangelical practices. As one of the most widely utilized forms of alternative medicine, chiropractic enjoys dual cultural citizenship; from the perspective of many consumers, it shares the prestige of modern science while appealing to anti-modern longings for "natural," spiritually pure remedies. ${ }^{9}$ As the chiropractic profession developed and fragmented after Palmer's discovery into a tradition-in-tension within itself, the label "chiropractic" proved remarkably malleable to evolving public discourses of biomedicine, metaphysics, and Christianity. In a bid for acceptance within the medical mainstream, spokespersons for the major chiropractic organizations developed promotional literature using scientific-sounding terminology that muted the religious overtones of chiropractic philosophy. Simultaneously, chiropractors who combined ideas derived from Palmerian metaphysics and conservative Christianity appealed to spiritually hungry seekers and pain-motivated evangelical and Charismatic co-religionists.

The story of chiropractic's mainstreaming is one of strategic marketing meeting a receptive culture poised to accept therapeutic benefits. Over the course of the

\footnotetext{
${ }^{4}$ This essay accepts Albanese's definition of "metaphysical" as referring to an emphasis on "mind" that includes not only reason, but also intuition, clairvoyance, and correspondence between mind and spirit; Albanese, Republic of Mind and Spirit, 6. The essay likewise accepts David Bebbington's classic definition of "evangelical" as including a focus on conversionism, biblicism, activism, and crucicentrism; Bebbington, Evangelicalism in Britain: A History from the 1730s to the 1980s (London: Unwin Hyman, 1989), 2-17.

${ }^{5}$ Albanese, Republic of Mind and Spirit, 515.

${ }^{6}$ Holly Folk, "Vertebral Vitalism: American Metaphysics and the Birth of Chiropractic" (PhD diss., Indiana University, 2006), 317.

${ }^{7}$ Philip Rieff, The Triumph of the Therapeutic: Uses of Faith After Freud (New York: Harper \& Row, 1966).

${ }^{8}$ David D. Hall, ed., Lived Religion in America: Toward a History of Practice (Princeton, N.J.: Princeton University Press, 1997); Laurie F. Maffly-Kipp, Leigh Eric Schmidt, and Mark R. Valeri, eds., Practicing Protestants: Histories of Christian Life in America, 1630-1965 (Baltimore: Johns Hopkins University Press, 2006).

${ }^{9}$ Catherine L. Albanese, Nature Religion in America: From the Algonkian Indians to the New Age, Chicago History of American Religion (Chicago: University of Chicago Press, 1990), 136.
} 
twentieth century, chiropractic spokespersons seeking a clientele adopted vocabularies that reconstituted what chiropractic's founders had envisioned as a philosophical alternative to Christianity as a profession at once scientific, spiritual, and Christian. Evangelical patients who worried about theological orthodoxy yet desired pain relief reclassified chiropractic as a legitimate, scientific complement to medicine and prayer for divine healing. In a culture in which pain has been emptied of positive religious meanings, the drive to avoid pain led many Americans to nuance their understandings of science, chiropractic, and Christianity so that they are experienced as complementary. ${ }^{10}$

This essay advances the following thesis: Although chiropractic began as a culturally marginal movement that rejected Christianity as well as modern medicine, by the late twentieth century it became a mainstream healing practice used by conservative Christians among others who had come to view chiropractic as consonant with their spiritual and scientific views. This major cultural adjustment occurred because chiropractic's organizers and practitioners deftly moved back and forth among physical and spiritual vocabularies depending on the context, finding a clientele among Americans whose need for healing made them receptive to chiropractic claims. This argument builds through four essay sections that make the following sub-claims: (1) chiropractic began as a metaphysical alternative to Christianity and modern medicine, a philosophical legacy from which current chiropractic has not altogether departed; (2) chiropractic developed as a tradition-in-tension within itself, overcoming substantial barriers to cultural acceptance by weaving between scientific and spiritual discourses in American culture; (3) reversing a decades-long mutual animosity, chiropractors sought and won acceptance among conservative Christians who reclassified chiropractic, based on perceived efficacy in relieving pain, as legitimate "science" rather than illegitimate "New Age" spirituality; and (4) original ethnographic research on Charismatic Christians who combine chiropractic, medicine, and prayer for divine healing illustrates the interconnectedness of metaphysical, scientific, and evangelical strands of a therapeutic culture where those in need of healing piece together diverse resources in an effort to meet practical needs. This story of pragmatically-driven combinative religion begins with chiropractic's metaphysical origins.

\section{The Metaphysical Philosophy of Early Chiropractic}

Many observers of chiropractic today assume that the practice has always been a non-religious healthcare option much like modern medicine, but less interventionist and more natural. Those who are aware of chiropractic's

\footnotetext{
${ }^{10}$ David B. Morris, The Culture of Pain (Berkeley: University of California Press, 1991), 4.
} 
metaphysical origins tend to assume that the practice entered the cultural mainstream because it shed its religious philosophy. The story of chiropractic's cultural mainstreaming is in actuality more complex and interesting than either group of observers has realized.

Chiropractic developed out of vitalistic, harmonial religious philosophies envisioned by their adherents as alternatives to Christianity. By contrast to interpretations of Christianity that emphasize the otherness of a Creator God from whom the created order has become alienated through sin, which requires reconciliation purchased through the atoning death and resurrection of the sinless Jesus Christ, harmonial traditions emphasize the ontological unity of God and Nature and the possibility of restoring cosmic rapport without reference to sin or redemption. During the nine years preceding his discovery, D. D. Palmer practiced "animal magnetism," a religious healing art rooted in the philosophies of Paracelsus (1493-1541), Athanasius Kircher (1602-1680), and Franz Anton Mesmer (1734-1815) and introduced in the United Stated by Charles Poyen in 1836. Animal magnetism, or mesmerism, presupposes that humans possess a magnetic field, today often referred to as an "aura," which can be used to heal disease by attracting the good or evil that endows all matter. Hypothesizing the existence of "magnetic ether" that flows through the solar system into the human nervous apparatus, mesmerists-like chiropractors, spiritualists, bonesetters, mind cure healers, and osteopaths-use hand gestures or "passes" to remove "obstructions" in the flow of "spirit" or "vital fluid" and restore "harmony" between the human body and the cosmos. ${ }^{11}$

D. D. Palmer was a religious eclectic who viewed chiropractic as the culmination of his spiritual explorations. A self-styled "Spiritualist," Palmer attributed chiropractic principles to spiritual "communications" from a deceased physician. ${ }^{12}$ Palmer coined the term "chiropractic" in 1896, after

\footnotetext{
${ }^{11}$ Moore, Chiropractic in America, 7-9; Robert S. Ellwood, Jr., "The American Theosophical Synthesis," in The Occult in America: New Historical Perspectives, ed. Howard Kerr and Charles L. Crow (Urbana: University of Illinois Press, 1983), 151; Sydney E. Ahlstrom, A Religious History of the American People, 2nd ed. (New Haven, Conn.: Yale University Press, 2004), 51; Perry Miller, "From Edwards to Emerson," in Errand into the Wilderness (Cambridge, Mass.: Harvard University Press, 1956), 191; P. A. Angeles, Dictionary of Philosophy (New York: Harper \& Row, 1981), 87; Folk, "Vertebral Vitalism," 109-25. Ernst Benz, The Theology of Electricity: On the Encounter and Explanation of Theology and Science in the 17th and 18th Centuries, trans. Wolfgang Taraba (Allison Park, Pa.: Pickwick, 1989), 5-14. For the appeal of vitalism to some evangelicals, see W. R. Ward, Early Evangelicalism: $A$ Global Intellectual History, 1670-1789 (New York: Cambridge University Press, 2006), 11.

${ }^{12}$ Palmer, Chiropractor's Adjuster, 718, 501; Russell W. Gibbons, "Chiropractic in America: The Historical Conflicts of Cultism \& Science," Journal of Popular Culture 10, no. 4 (1977): 721; Joseph H. Donahue, "D. D. Palmer and the Metaphysical Movement in the Nineteenth Century," Chiropractic History: The Archives and Journal of the Association for the History of Chiropractic 7, no. 1 (1987): 23-25.
} 
asking a patient, the Presbyterian Reverend Samuel $\mathrm{H}$. Weed, to suggest several Greek names. Combining the words cheir, hand, and praktos, done, chiropractic means "done by hand."13 Catherine Albanese has suggested that Palmer selected the term over alternatives after seeing references to "cheiromancy," or palm reading, in metaphysical literature, which Palmer read avidly. Just as palmists "read human destiny in nature's imprint on each individual human hand," chiropractors were spiritual visionaries who "read health or disease in the body structure of the spine." 14

Given Palmer's religious interests, it is not surprising that he considered defining chiropractic as a "religion." 15 Instead, he heralded chiropractic as a middle ground between Christian Science and medicine. ${ }^{16}$ Palmer articulated his understanding of chiropractic as uniquely integrating spirit and matter in a 985-page textbook entitled The Chiropractor's Adjuster. Text-book of the Science, Art and Philosophy of Chiropractic for Students and Practitioners (1910). "The New Theology" of healing or the "religion of chiropractic," to quote Palmer, was founded upon a "religious plank," which he termed "Innate Intelligence," or simply "Innate." ${ }^{17}$ Palmer explained: "That which I named innate (born with) is a segment of that Intelligence which fills the universe," a "part of the Creator." Innate is synonymous with "the Greek's Theos, the Christian's God, the Hebrew Helohim, the Mahometan's Allah, Hahneman's [sic] Vital Force, New Thot's [Thought's] Divine Spark, the Indian's Great Spirit, Hudson's Subconscious Mind, the Christian Scientist's All Goodness, the Allopath's Vis Medicatrix Nature."18 Palmer insisted that chiropractic could not be practiced effectively apart from a philosophy that he thought captured the essence of the world's religious and medical systems.

\footnotetext{
${ }^{13}$ Vern Gielow, Old Dad Chiro: Biography of D D. Palmer, Founder of Chiropractic (Davenport, Iowa: Bawden Bros., 1981), 82-83.

${ }^{14}$ Albanese, Nature Religion, 149-50.

${ }^{15}$ Conversation with Vern Gielow (1982) reported by Albanese, Nature Religion, 151; Steven C. Martin, "'The Only Truly Scientific Method of Healing': Chiropractic and American Science, 1895-1990" Isis 85, no. 2 (1994): 213. Walter I. Wardwell, Chiropractic: History and Evolution of a New Profession (St. Louis: Mosby-Year Book, 1992), 180-81, uniquely among the sources I have studied, denies that Palmer considered chiropractic a religion. After quoting a lengthy passage from Palmer that identifies the "religion of chiropractic" as belief in Universal Intelligence, "segmented into as many parts as there are individual expressions of life," Wardwell summarily protests: "If this is religion, it certainly is not Christian. Basically, D. D. did not consider chiropractic a religion"; Wardwell's word choice suggests that Palmer's explicitly "religious" views did not strike Wardwell as "Christian" and that Wardwell considered theistic religions such as Christianity to be the only genuine religions.

${ }^{16}$ Moore, Chiropractic in America, 23; Martin, "Only Truly Scientific Method," 213.

${ }^{17}$ Palmer, Chiropractor's Adjuster, 446, 642; D. D. Palmer, The Chiropractor (Los Angeles: Press of Beacon Light Printing, 1914), 10, published posthumously by Palmer's wife through a spiritualist publishing house (see Donahue, "Metaphysical Movement," 26), and qtd. in Wardwell, Chiropractic, 180.

${ }^{18}$ Palmer, Chiropractor's Adjuster, 491, 691, 493.
} 
Embracing vitalistic, harmonial religious ideas abroad in the culture, Palmer's genius lay in his ability to theorize a mechanism by which a spiritual force directs the material universe. ${ }^{19}$ "We are well," announced Palmer, "when Innate Intelligence has unhindered freedom to act thru the physical brain, nerves and tissues.... Diseases are caused by a LACK OF CURRENT OF INNATE MENTAL IMPULSES."20 Even a minor displacement, or "subluxation," of spinal vertebrae causes tension or laxity in nerve "tone," altering the vibratory transmission rate of the nerves. Vertebral "adjustments" restore nerve tone, allowing Innate Intelligence to "care for and direct the functions of the body." For Palmer, the necessity of keeping individuals adjusted to Innate had implications for the cosmic evolutionary process that gave the chiropractor a religious mandate: "Knowing that our physical health and the intellectual progress of Innate (the personified portion of Universal Intelligence) depend upon the proper alignment of the skeletal frame, prenatal as well as postnatal, we feel it is our right and bounden duty to replace any displaced bones, so that the physical and spiritual may enjoy health, happiness and the full fruition of earthly lives.." ${ }^{21}$ In Palmer's view, chiropractors had a religious duty not only to remedy diseases but also to perform an act of service to Innate by adjusting human spines.

As leadership of the fledgling chiropractic profession passed from D. D. Palmer to his son, Bartlett Joshua Palmer (1881-1961), its religious distinctiveness from Christianity intensified rather than faded. B. J. Palmer headed the Palmer School of Chiropractic in Davenport, Iowa (founded by D. D. in 1897) for fifty years, during which time he trained an estimated $75 \%$ of all chiropractors. ${ }^{22}$ Despite bitter disagreements among chiropractors, for the first half of the twentieth century, no individual was as influential as B. J. Palmer in shaping and speaking for the profession. Although D. D. had been cautious not to offend those with Christian beliefs, B. J. argued provocatively that "the great men of all times, the men who have done things, have been either rank theological-Biblical-infidels or agnostics."23 Revisiting his father's idea of declarıng chiropractic a religion, B. J. decided against it on the grounds that chiropractic has no use for a "deity to which we can direct instructions of how to run the universe, or a soul to save for

\footnotetext{
${ }^{19}$ Fuller, Alternative Medicine, 72

${ }^{20}$ The Chiropractor 5 (1909) frontıspiece (Davenport, Iowa Palmer School of Chiropractıc Publisher, 1909), qtd in Fuller, Alternattve Medicine, 72

${ }^{21}$ Palmer, Chiropractor's Adjuster, 492, 8

${ }^{22}$ Joseph C Keating and Association for the History of Chiropractic, $B J$ of Davenport The Early Years of Chiropractic (Davenport, lowa Association for the History of Chiropractic, 1997), vi

${ }^{23}$ B J Palmer, Do Chiropractors Pray? (Davenport, Iowa Palmer School of Chiropractıc, n d ), 25 (emphasis in onginal)
} 
heaven or from hell."24 Asking the question, Do Chiropractors Pray? B. J. answered definitively that "no Chiropractor would pray on his knees in a supplication to some invisible power." ${ }^{25}$ B. J. conceptualized "Innate Intelligence WITHIN man as the all-wise, omnipotent, omniscient, omnipresent Director-General who asserts that THE ONLY possible cause and cure are wITHIN man."26 Because "it is interference with the supply of mental impulse that is back of every dis-ease," instead of pray (or employ medical treatments), "the thing to be done is to adjust the (cause) subluxation."27 Given B. J. Palmer's understanding of chiropractic as an incompatible alternative to Christianity and biomedicine, it is noteworthy that many of the chiropractors he trained attracted extensive clienteles by integrating the Palmers' metaphysical philosophy with science, seeker spintuality, and evangelicalism.

At the turn of the twenty-first century, most chiropractors recognize D. D. and B. J. Palmer as the "discoverer" and the "developer" of the profession, but there is not a consensus about the significance of the Palmers' religious philosophy to the "science" and "art" of modern chiropractic. Indeed, the relevance of early chiropractic philosophy to modern chiropractic is hotly contested not only among chiropractors but also among scholars of chiropractic and alternative medicine, some of whom adopt a tone that suggests a personal stake in whether or how chiropractic is "religious."28 The meanings of chiropractic are culturally charged, making neutral historical and cultural analysis difficult to achieve. Intense intramural rivalries have marked the history of chiropractic from the beginning. Often referred to as a division between "straights" and "mixers" (purists who held closely to the Palmers' philosophy vs. experimentalists who added other therapeutic approaches), the historian J. Stuart Moore has suggested that it is more useful to think of a distinction between "harmonial" and "mechanical" chiropractors. $^{29}$ The former group pursued the goal of restoring harmony with universal life-force energy, with "mixers" further emphasizing parallels between Innate and energy concepts in other vitalistic traditions, such as qi,

\footnotetext{
${ }^{24} \mathrm{~B} \mathrm{~J}$ Palmer, The Bigness of the Fellow Within (Davenport, Iowa Chiropractic Fountain Head, 1949), 65, cf B J Palmer's reflections on declaring chiropractic a religion, Lecture Notes, October 21, 1908, 4, Archives, Palmer College of Chiropractic, qtd in Martın, "Chiropractic and the Social Context of Medical Technology," 813, 816, Martin, "Only Truly Scientific Method," 213

${ }^{25} \mathrm{~B}$ J Palmer, Do Chiropractors Pray? 27

${ }^{26} \mathrm{~B}$ J Palmer, Up From Below the Bottom (Davenport, Iowa Chiropractic Fountain Head, 1950, reprint 1991), 2, cf B J Palmer, The Lord's Work (Davenport, Iowa Palmer School of Chiropractıc, n d), 9, B J Palmer, Our Masterpiece (Davenport, lowa Palmer College of Chiropractic, 1966), 116

${ }^{27} \mathrm{~B}$ J Palmer, Do Chiropractors Pray? 28, cf B J Palmer, The Glory of Going On (Davenport, Iowa Palmer School of Chiropractic, 1961), 56, 71-72, B J Palmer, Fight To Climb (Davenport, Iowa Chiropractic Fountain Head, 1950), 537-38 (emphasis in onginal)

${ }^{28}$ See, for example, Wardwell, Chiropractic, 180, discussed above in note 15

${ }^{29}$ Moore, Chiropractic in America, 49-50
} 
prana, or vital force, and incorporating practices such as acupuncture, yoga, and homeopathy drawn from these traditions. The latter group downplayed the Palmers' vitalistic philosophy and sought a modern, scientific rationale for spinal manipulations. Significantly, however, the first-ever profession-wide survey of chiropractors conducted in 2003 concludes that "Nearly $90 \%$ want to retain the VSC [Vertebral Subluxation Complex] as a term. Similarly, almost $90 \%$ do not want the adjustment limited to musculoskeletal conditions. The profession-as a whole-presented a united front regarding the subluxation and the adjustment. ... When it comes to broad [that is, mixer] scope and focused [that is, straight] scope chiropractors, the old stereotypes are misleading. ... On most issues, broad scope and focused scope chiropractors differ more in degree, than in kind." ${ }^{30}$ Chiropractic historians who feel uncomfortable with the Palmers' religious views, embarrassed by their anti-medical statements, and eager for the profession to achieve scientific legitimacy have (unjustifiably in Moore's view) minimized the ongoing influence of harmonial chiropractic. For instance, a history of chiropractic commissioned by the National Chiropractic Malpractice Insurance Company (NCMIC) Group, Inc., written by an attorney representing the profession, David Chapman-Smith, downplays B. J. Palmer's influence by characterizing him as the leader of a "vocal minority" in contrast to the "growing mainstream that set about developing mature standards of education and practice." ${ }^{31}$ Instead of providing quantitative evidence, Chapman-Smith employs terms such as "growing mainstream" and "mature" to portray "scientific" chiropractic as normative and developmentally superior to the Palmers' explicitly over-talkative and implicitly immature and, hence, decreasingly influential religious views. Although acknowledging the challenge of generalizing about any practice as internally divided and externally contested as chiropractic, one of the conclusions reached by the present study is that the "harmonial" tradition has played an ongoing role in modern chiropractic (for many mixers as well as straights), but this role has been greatly underestimated for historical and cultural reasons explored in the following section. ${ }^{32}$

\footnotetext{
${ }^{30}$ William P. McDonald, How Chiropractors Think and Practice: The Survey of North American Chiropractors (Ada, Ohio: Institute for Social Research, Ohio Northern University, 2003), 20-21; this survey is further discussed below.

${ }^{31}$ David Chapman-Smith, The Chiropractic Profession: Its Education, Practice, Research and Future Directions (West Des Moines, Iowa: NCMIC Group, 2000), 14.

${ }^{32}$ Steven C. Martin, "Chiropractic and the Social Context of Medical Technology," 831, concurs that scholars such as Fuller (Alternative Medicine, 71, 76) underestimate the persistence of spirituality in modern chiropractic.
} 


\section{Adjusting Chiropractic's Religious and Cultural Meanings}

For seventy-five years commonly referred to as a "medical cult"-a term suggestive of the relationship between perceptions of medically and religiously marginal status in American culture-chiropractic had gained legitimacy in the eyes of many Amencans by the final quarter of the twentieth century. The reason for chiropractic's new-found acceptance is not simply that modern chiropractors jettisoned a religious philosophy that many Americans found objectionable. Rather, chiropractors deftly straddled spiritual, scientific, and evangelical vocabularies in presenting themselves to diverse constituencies. There is a complex social, legal, and economic context to this story, which has been ably treated elsewhere. ${ }^{33}$ In brief, not only did early chiropractors and medical doctors disagree philosophically, but for several decades chiropractors also appealed to members of the rural, working-class, who were socially distanced from more genteel, professionally educated allopathic medical practitioners, which in turn aggravated medical disdain for chiropractic. As late as 1963, the American Medical Association's (AMA) Committee on Quackery formed with the mandate "to contain and eliminate chiropractıc."34 Although philosophically similar enough to osteopathy that founder Andrew Taylor Still (1828-1917) accused Palmer of stealing his ideas, osteopathy more quickly shed its sectarian reputation-in part because of the more genteel social origins of early osteopaths and in part because osteopaths were quicker to embrace biomedical reasoning and methods-and gained Medicare coverage in 1965. By the 1970s, a movement withın chiropractic had worked to overcome social and educational barriers to acceptance by standardizing educational and licensing requirements. As of 1974, chiropractic licensing laws were in effect in all fifty states, and the U.S. Office of Education had established an accrediting agency for chiropractic colleges, which made accredited colleges eligible for federal funding; that same year, Congress authorized the expenditure of two million dollars for studies to establish a scientific basis for spinal manipulation. Chiropractors also sought legitimacy through the courts. Charging the AMA (and eleven other healthcare associations, including the American Osteopathic Association) with unfair competition, chiropractors won a major victory with Wilk $v$ AMA $(1987 ; 1990)$, which forbade the AMA from discriminating against chiropractors; meanwhile, as

\footnotetext{
${ }^{33}$ See, for example, Whorton, Nature Cures, 17, 285, Moore, Chiropractic in America, 130, Walter I Wardwell, "Before the Palmers An Overview of Chiropractic's Antecedents," Chiropractic History The Archives and Journal of the Association for the History of Chiropractic 7, no 2 (1987) 30

${ }^{34}$ Wilk v American Medical Assoc , 671 F Supp 1465, 1473 (N D Ill 1987), aff'd, 895 F 2d 352 (7th Cir 1990), cert denied, 498 U S 982, 111 S Ct 513 (1990)
} 
clinical studies suggested the cost effectiveness of chiropractic, insurance plans added coverage.

By the 1990s, it was common for chiropractors and medical doctors to practice in the same clinics and hospitals, often in formal partnerships. This is not to say that expressions of disdain for chiropractic, especially by those invested in allopathic or osteopathic medicine, disappeared; yet, historian James Whorton aptly describes the "present-day spirit of cooperation" between medical doctors and chiropractors as "an extraordinary reversal of a mutual animosity." ${ }^{35}$ Indeed, the journal of the AMA published a special issue on alternative medicine in 1998, which included reports on clinical trials of seven unconventional therapies, four of which (chiropractic, acupuncture, yoga, and herbs) found benefits. ${ }^{36}$ In 1991, Congress established an Office of Alternative Medicine at the National Institutes of Health, upgrading its status in 1998 to a National Center for Complementary and Alternative Medicine. The recent acceptance of chiropractic as a mainstream healthcare option is suggested by shifts in terminology-from being denounced as a "medical cult" in the 1960s, chiropractic was identified as a medical "alternative" in the 1980 s, and finally achieved the status of "complementary medicine" by the close of the $1990 \mathrm{~s} .{ }^{37}$ The number of chiropractors grew from 16,000 in 1930 to 66,000 in $2000-57,000$ of whom worked in the United States, making chiropractic a distinctly American phenomenon. Treating five million people annually, practitioners have adjusted an estimated $10 \%$ of the U.S. population. ${ }^{38}$

Chiropractic is one of numerous healing alternatives that have grown up alongside and become rooted within the reigning scientific paradigm. ${ }^{39}$ Usage rates of alternative therapies remained relatively constant throughout the twentieth century (estimated by surveys at 34\% in both 1924 and 1990), but the cultural position of alternative healthcare shifted from periphery to center. ${ }^{40}$ In $1930,25 \%$ of American "healers" were "irregulars of some

\footnotetext{
${ }^{35}$ Whorton, Nature Cures, 17.

${ }^{36}$ Alternative Medicine: An Objective Assessment, Journal of the American Medical Association 280, no. 18 (November 11, 1998): 1551-640, qtd. in Whorton, Nature Cures, x.

${ }^{37}$ Whorton, Nature Cures, x, 243, 295; M. Herron and M. Glasser, "Use of and Attitudes Toward Complementary and Alternative Medicine Among Family Practice Patients in Small Rural Illinois Communities," Journal of Rural Health 19, no. 3 (2003): 279.

${ }^{38}$ U. S. Department of Health, Education, and Welfare (1965), qtd. in Marjorie White and James K. Skipper, Jr., "The Chiropractic Physician: A Study of Career Contingencies," Journal of Health and Social Behavior 12, no. 4 (December 1971): 300; Glenda Wiese, "Chiropractic History and Trivia," in Chiropractic Secrets, ed. Seth Gardner and John S. Mosby (Philadelphia: Hanley \& Belfus, 2000), 242-45.

${ }^{39}$ Michael F. Brown, The Channeling Zone: American Spirituality in an Anxious Age (Cambridge, Mass.: Harvard University Press, 1997), 6.

${ }^{40}$ Whorton, Nature Cures, xiii, 223, 245-49; David M. Eisenberg, , "Unconventional Medicine in the United States: Prevalence, Costs, and Patterns of Use," New England Journal of Medicine
} 
stripe," including chiropractors, osteopaths, naturopaths, and Christian Scientists. ${ }^{41}$ Alternative healers survived the regulatory assaults of medical and religious authorities by forging connections with oppositional political cultures. ${ }^{42}$ Advances in scientific medicine in the early twentieth century gave the maturing medical profession cultural and political authority, which increased with the introduction of sulfa drugs in the 1930s, antibiotics in the 1940 s, and "wonder drugs" in the 1950s. By the 1970s, patients were more aware of drug side effects, and felt frustrated by the rising costs and limited accessibility of conventional medical treatment, the depersonalization of care resulting from medical specialization, and the "presumptive expertise" of physicians who interpreted every illness within a biochemical construct of disease. ${ }^{43}$ The political pull of alternative healing increased dramatically with the rise of the counterculture of the 1960s and the "holistic" healthcare movement of the 1970s. Chiropractors in the holistic healthcare movement attracted clients by emphasizing their harmonial philosophy and incorporating other therapeutic alternatives that similarly view humans as interdependent bodies, minds, emotions, and spirits. ${ }^{44}$

Chiropractic thrived on the borders of competing epistemologies, appealing simultaneously to the scientific and spiritual strains of American culture. By the 1980s, those chiropractors who felt embarrassed by the Palmers' seemingly premodern religious views and eager for the profession to achieve legitimacy, publicly redefined chiropractic as "scientific." Adopting what historian R. Laurence Moore calls a "rhetoric of denial," these spokespersons obscured the importance of religion to chiropractic and hastened the profession's move to the mainstream. ${ }^{45}$ Peter Boyner's 1987 article, "Isn't It

328, no. 4 (January 28, 1993): 246-52; David M. Eisenberg, , "Trends in Alternative Medicine Use in the United States, 1990-1997: Results of a Follow-Up National Survey," Journal of the American Medical Association 280, no. 18 (November 11, 1998): 1569-75.

${ }^{41}$ Louis Schultz Reed, The Healing Cults. A Study of Sectarian Medical Practice; Its Extent, Causes, and Control (Washington, D.C.: Committee on the Costs of Medical Care, 1932), 1; Ronald L. Numbers, "The Fall and Rise of the American Medical Profession," in Sickness and Health in America: Readings in the History of Medicine and Public Health, ed. Judith Walzer Leavitt and Ronald L. Numbers, 3rd ed. (Madison: University of Wisconsin Press, 1997), 233.

${ }^{42}$ Robert D. Johnston, The Politics of Healing: Histories of Alternative Medicine in TwentiethCentury North America (New York: Routledge, 2004), 2.

${ }^{43}$ Whorton, Nature Cures, 245-49.

${ }^{44}$ Martin, "Only Truly Scientific Method of Healing," 224; Fuller, Alternative Medicine, 90, 92; Whorton, Nature Cures, xii, 4, 246, 24. The South African philosopher Jan Smuts coined the term "holism," from the Greek holos, or whole, in a book entitled, Holism and Evolution (New York: MacMillan, 1926), that practitioners of holistic medicine had revived by the 1980s.

${ }^{45} \mathrm{R}$. Laurence Moore, "The Occult Connection?: Mormonism, Christian Science, and Spiritualism," in Occult in America, ed. Kerr and Crow, 151; Steven C. Martin, "Chiropractic and the Social Context of Medical Technology, 1895-1925," Technology and Culture, Special Issue: Biomedical and Behavioral Technology 34, no. 4 (October 1993): 831. 
Time to Abandon Anachronistic Terminology?" laments that references to "innate intelligence" and "vitalism" continued to pervade modern chiropractic literature. ${ }^{46}$ Implicitly, chiropractors writing in professional journals in the 1980 s used metaphysical vocabulary similar to that introduced by the Palmers. Boyner, whose avowed goal is the integration of chiropractic into the healthcare system, considers religious-sounding terminology an impediment to scientific credibility. Unless chiropractors can shed their "dogmatic"-sounding language, Boyner opines, "what justification is there that chiropractic is not a religion?" Boyner, like other proponents of modernizing chiropractic terminology, advocates replacement of terms like "innate" and "vitalism" with religiously neutral sounding terms such as "homeostasis" and "holism." The principle of homeostasis can, without mention of Innate, affirm the "ability of the body to repair itself in certain optimal circumstances." Holism can likewise be unmoored from references to vitalism and still express an "inherent property of complex systems to maintain and enhance complexity against the dissipative tendency which is embodied in the second law of thermodynamics." Boyner is less concerned with developing an alternative philosophy for chiropractic than with presenting the profession to the public using the language of science.

Chiropractors sympathetic to Boyner's agenda of linguistic modernization have, in the 1990s and 2000s, shaped the policy statements issued by every major chiropractic organization. In typical fashion, the American Chiropractic Association's (ACA) "Policy Statement" (1994) employs purely mechanical terminology to define an "adjustment" as "any chiropractic therapeutic procedure that utilizes controlled force, leverage, direction, amplitude and velocity which is directed at specific joints or anatomical regions." 47 Official brochures typically compare "Innate" with more scientific-sounding concepts like "electricity" or "nerve force," or dispense with the term altogether. ${ }^{48}$ Substituting "inherent" for "innate," the Association of Chiropractic Colleges' "Position Paper" (1996) defines chiropractic as a "health care discipline that emphasizes the inherent recuperative power of the body to heal itself without the use of drugs or surgery." ${ }^{, 9}$ Innate is now one of several terms rather than a unifying concept, and it connotes a physiological rather than a spiritual property: the "body's innate recuperative power is affected by and integrated through the nervous

\footnotetext{
${ }^{46}$ Peter Boyner, "Isn't It Time to Abandon Anachronistic Terminology?" Journal of the Australian Chiropractors' Association 17, no. 2 (1987): 53, 54, 56, 57.

${ }^{47}$ American Chiropractic Association, "Policy Statement" (1994), qtd. in Chapman-Smith, Chiropractic Profession, 58.

${ }^{48}$ Whorton, Nature Cures, 184.

${ }^{49}$ Association of Chiropractic Colleges, "Position Paper" (1996), qtd. in Chapman-Smith, Chiropractic Profession, 57, 60.
} 
system." The World Chiropractic Alliance's (WCA) "Practice Guidelines for Straight Chiropractic" (1993) similarly emphasize the physiological attributes of subluxations, redefined as an "alteration of nerve function and interference to the transmission of mental impulses, resulting in a lessening of the body's innate ability to express its maximum health potential." ${ }^{\text {50 }}$ Remaining silent about chiropractic philosophy, promotional literature oriented toward the medical mainstream recasts chiropractic in language congenial to modern, scientific sensibilities.

The prevalence of scientific-sounding language in promotional materials designed to garner biomedical acceptance does not necessarily imply that most modern chiropractors have abandoned early chiropractic philosophy. To the contrary, there is reason to doubt the disappearance of metaphysics from much of modern chiropractic. The chiropractic historian Joseph Donahue estimated in 1992 that - in his view regrettably- $80 \%$ of chiropractors "subscribe to some version" of Innate, a doctrine whose influence has been "far greater than it should have been," in Donahue's view, "considering its scientific merit." a few hundred" chiropractors - of a total that by the year 2000 had climbed to 66,000-reject the Palmers' philosophy and merely treat "neuromusculoskeletal conditions of a nonsurgical nature." A2 Among this group are the several hundred members of the National Association for Chiropractic Medicine (NACM), founded in 1984, who explicitly "renounce the chiropractic hypothesis and/or philosophy" that "subluxation is the cause of dis-ease," and "confine their scope of practice to the treatment of joint dysfunctional disorders"; ${ }^{53}$ the NACM is, however, a self-consciously minority organization that has been strongly criticized by major organizations such as the 15,000 -member ACA (the single largest chiropractic organization) and the 8,000 -member International Chiropractors' Association (ICA) for limiting the scope of chiropractic. Analyzing ACA and ICA marketing brochures targeted at patients-in contrast to policy statements issued by these same organizations for an audience that includes medical professionals and funding agencieschiropractic researchers Joseph C. Keating, Jr., et al. (2005) concluded that it

\footnotetext{
${ }^{50}$ World Chiropractic Alliance, "Practice Guidelines for Straight Chiropractic" (1993), qtd. in Jack Raso, "Alternative" Healthcare: A Comprehensive Guide (Amherst, N.Y.: Prometheus Books, 1994), 150.

${ }^{51}$ Joseph H. Donahue, "The Trouble With Innate and the Trouble that Causes," Philosophical Constructs for the Chiropractic Profession 2, no. 1 (1992): 23; Joseph H. Donahue, "D. D. Palmer and Innate Intelligence: Development, Division and Derision," Chiropractic History: The Archives and Journal of the Association for the History of Chiropractic 6 (1986): 35.

${ }^{52}$ Raso, "Alternative" Healthcare, 148.

${ }^{53}$ National Association for Chiropractic Medicine, official website, http://www.chiromed.org/ (accessed August 20, 2007; emphasis in original).
} 
is "commonplace in the profession," in patient brochures and clinical practice, for chiropractors to couple the "vitalistic concepts of 'Innate Intelligence"" with the "magic and mystery" of "subluxation dogma." " One chiropractic patient wrote, in 2009, a revealing description of how her chiropractor communicated his metaphysical views: "In the chiropractic waiting room (in the Bible Belt), I sit in one of the four chairs, all of which face a small television. Today and every other day for the last year, Rhonda Byrne's breakaway hit, The Secret (2007), is playing on endless rotation, urging viewers to direct their thoughts toward achieving their desires." 55 The TV was surrounded by brochures for detoyxifying footbaths, anti-stress capsules, and kinesiology/energy medicine; a provided list of health resources directed patients to Deepak Chopra, Transcendental Meditation, acupuncture, homeopathy, naturopathy, Pilates, and yoga. ${ }^{56}$ When the chiropractor entered the waiting room, he explained that "we attract the positive or negative into our lives. He chose the video, he said, because he agrees with that message."

Large-scale survey research on chiropractic attitudes and practices confirms anecdotal evidence that most chiropractors share harmonial views. The Institute for Social Research at Ohio Northern University published the results of a groundbreaking survey, How Chiropractors Think and Practice: The Survey of North American Chiropractors (2003). ${ }^{57}$ The principal investigator, William McDonald, is himself a chiropractor who presents the study as demonstrating the profession's overwhelming "unity" and capacity to participate in an "interdisciplinary health care environment." Using Dynamic Chiropractic's list of 60,409 currently practicing chiropractors to generate a random pool of 1,102 names from every state in the United States and several regions in Canada and Mexico, the survey yielded a response rate of 687 chiropractors, or $63.3 \%$ of those polled. The study found that the "typical North American chiropractor," regardless of whether self-classified as Broad Scope/Mixer (34.3\%), Focused Scope/Straight (19.3\%), or Middle Scope $(46.6 \%)$, believes that "adjustment should not be limited to musculoskeletal conditions" (89.8\%), "subluxation" is a "significant contributing factor in $62.1 \%$ of visceral ailments," and only $39.8 \%$ of prescribed medicines are beneficial; $50.1 \%$ of those surveyed question the pro-immunization medical position. Asked whether adjustments usually elicit

\footnotetext{
${ }^{54}$ Joseph C. Keating, Jr., Keith H. Charlton, Jaroslaw P. Grod, Stephen M. Perle, David Sikorski, and James F. Winterstein, "Subluxation: Dogma or Science?" Chiropractic \& Osteopathy 13, no. 17 (August 10, 2005), http://www.chiroandosteo.com/content/13/1/17 (accessed December 13, 2007).

${ }^{55}$ Personal communication to author, June 30, 2009.

${ }^{56}$ Brochures promoted the chiropractor's mentor, Stevens Chiropractic and Wellness, whose patient-directed literature lists a variety of health resources; Stevens Chiropractic and Wellness, "Health Resources," http://www.stevenswellness.com/custom_content/1380_health_resources. html (accessed July 7, 2009).

${ }^{57}$ McDonald, How Chiropractors Think, 15, 16, 35, 49, 55, 60, 89, 90, 91, 101.
} 
improvements in the following cases, chiropractors responded affirmatively for tension headache $(99.4 \%)$, migraine headache $(89.3 \%)$, dysmenorrhea/ menstrual pain (84.2\%), allergic-type asthma (75.5\%), and otitis media/ middle ear infections (77.0\%). The typical chiropractor "performs a broad spectrum of routine clinical services," including "periodic maintenance/ wellness care" (93.6\%), exercise recommendations (97.8\%), stress reduction recommendations $(86.4 \%)$, nutrition advice $(87.7 \%)$, vitamin/herbal recommendations $(72.0 \%)$, and "teaching a relationship between spinal subluxations and visceral health" (76.5\%). Super-majorities ( $75 \%$ or more) agree that chiropractic's scope of practice appropriately includes alternative therapies that, like chiropractic, are closely connected with vitalistic philosophies, such as acupressure $(94.0 \%)$, acupuncture $(76.8 \%)$, massage (93.1\%), herbs $(91.1 \%)$, and homeopathic medicines $(82.1 \%) .{ }^{58}$

How aware are patients are of their chiropractors' philosophical commitments? The official legal counsel for the National Chiropractic Malpractice Insurance Company (an organization that provides coverage to 37,000 chiropractors), David Chapman-Smith (cited earlier as seeking to minimize the influence of the Palmers' philosophy) helps to answer this question. In spite of his desire to rescue chiropractic from charges of religious backwardness, he recognizes the growing popularity of Complementary and Alternative Medicine (CAM). Chapman-Smith positions chiropractic squarely within this tradition and asserts that consumers are "pulled towards" chiropractic and other forms of CAM for the very reason that providers regularly communicate to their patients the philosophical differences between CAM (which assumes the interconnectedness of body, mind, and spirit) and biomedicine (which is premised on mechanistic materialism). ${ }^{59}$ Chapman-Smith estimated in 2000 that two-thirds (an underestimate, based on the results of the Ohio survey) of chiropractors offer a variety of lifestyle prescriptions that prominently include CAM therapies. ${ }^{60}$ Although it is notoriously difficult to trace all the meanings ascribed to practices by providers or consumers, several of the remedies enumerated by Chapman-Smith-macrobiotic diets, mega-vitamin therapy, imagery, homeopathy, herbal medicine, energy healing, biofeedback, hypnosis, and acupuncture-developed out of healing traditions that, like chiropractic, assume the existence of a vital, universal energy that physical and/or mental practices can affect (for instance, by balancing yin and yang or redirecting the

\footnotetext{
${ }^{58}$ Interestingly, the study discussion (p. 59) suggests that acupuncture garners less support than acupressure because it is more "invasive," not because respondents question the vitalistic theory upon which it is based.

${ }^{59}$ E. K. Ledermann, Philosophy and Medicine (Brookfield, Vt.: Gower, 1986), 43.

${ }^{60}$ Chapman-Smith, Chiropractic Profession, 69-70, 135.
} 
flow of qi or prana). ${ }^{61}$ Indeed, the motion picture Jacob's Ladder (1990) suggests the resonance between chiropractic philosophy and an increasingly prevalent style of seeker spirituality that privileges experiences offering direct access to spiritual energy over institutional loyalty or creedal orthodoxy. ${ }^{62}$ In the film, the emotionally traumatized protagonist, Jacob Singer, cannot trust anyone he meets - except his chiropractor, Louis, who regularly adjusts him and gives him spiritual advice, offering him the only convincing explanation of the meanings of his life, death, and immortality. ${ }^{63}$ Chapman-Smith similarly suggests that, in a variety of real-life situations, individuals who might go to medical doctors and pray for divine healing also feel "pulled" toward the metaphysically premised prescriptions offered by their chiropractors.

Some chiropractic analysts insist that many of their peers unduly selfmonitor their communications to patients depending upon whether they expect them to be sympathetic to their harmonial philosophies. Such critics charge that those chiropractors who are chameleonic in their selfpresentation-personally embracing vitalistic views but adopting vague or scientific-sounding vocabularies when addressing patients who may not share their outlook-should be held culpable for violating an ethical responsibility to give patients the material information they need to provide informed consent to chiropractic adjustments. In the evaluation of chiropractic historian Joseph Donahue, $80 \%$ of chiropractors "evade professional accountability" by firing at patients a "barrage of quasi-scientific information" about particular techniques, while remaining intentionally

\footnotetext{
${ }^{61}$ For the shared vitalistic premises of many CAM therapies, see Whorton, Nature Cures, 10.

${ }^{62}$ For instance, a 2009 Newsweek poll found $30 \%$ of Americans identified themselves as "spiritual" rather than "religious," up from 24\% in 2005; Jon Meacham, "The End of Christian America," Newsweek (April 13, 2009), available at http://www.newsweek.com/id/192583 (accessed April 7, 2009). Surveys conducted by the Baylor Institute for Studies of Religion with the Gallup Organization in 2005 and 2007 found that $57 \%$ of Americans self-identified as both spiritual and religious, but only $10 \%$ identified as spiritual but not religious. Although much attention has been paid to recent polls finding that $11-12 \%$ of Americans have come to identify with "no religion," the Baylor surveys shed light on what people mean when they self-identify as such. The study concludes that "the percentage of atheists hasn't changed at all," found to be $4 \%$ by a 1944 Gallup poll and $4 \%$ by the 2007 Baylor survey. Instead, "what 'no religion' seems to mean to most who give this response is that they reject conventional religions, but not supernaturalism of more exotic sorts-two-thirds of them can be classified as New Agers ... [who are] very likely to accept occult and paranormal beliefs"; Rodney Stark, What Americans Really Believe: New Findings from the Baylor Surveys of Religion (Waco, Tex.: Baylor University Press, 2008), 117, 141, 144. On seeker spirituality, see Robert Wuthnow, After Heaven: Spirituality in America since the 1950s (Berkeley: University of California Press, 1998), 3-4; Wade Clark Roof, A Generation of Seekers: The Spiritual Journeys of the Baby Boom Generation (San Francisco: HarperSanFrancisco, 1993), 67, 259.

${ }^{63}$ Brian Keene, review of Jacob's Ladder, directed by Adrian Lyne, Carolco Pictures, http:// www.feoamante.com/Movies/JKL/jacobslad.html (accessed February 17, 2006); “Jacob's Ladder," The Internet Movie Database, http:/www.imdb.com/title/tt0099871 (accessed February 17, 2006).
} 
vague about the meanings of Innate Intelligence, because they realize that this "religious doctrine ... if understood by the patient, would be reprehensible to many of them." ${ }^{\text {"64 }}$ Chiropractic informed consent theorists Michael Burgess and Richard Steinecke have similarly charged many of their peers with using the "relative safety and non-invasiveness" of adjustments to justify their failure to meet medical standards of informed consent that would ethically require them to disclose that adjustments "could offend a religious, ethical or personal belief of the patient." ${ }^{\prime 65}$ According to such critics, chiropractors should be clearest in communicating their viewpoints not to those patients who already feel pulled toward harmonial philosophies but to those who might reject chiropractic if they better understood its specific doctrines.

Evidence suggesting that many chiropractors do hold and at least selectively communicate to their patients harmonial philosophies can be reconciled with the prevalence of scientific-sounding language in medically oriented promotional materials by noting that chiropractors are scarcely unique in finessing their self-presentation depending on the audience. Chiropractic discourse is particularly adept at weaving between physical and spiritual vocabularies given the metaphysical assumption of "correspondence," or organic connection and interpenetration, between material and spiritual realities. ${ }^{66}$ Thus, physical explanations such as those found in public policy statements can be envisioned as supplementing instead of replacing attributions of spiritual causality. Without reducing chiropractic philosophy to modern medical theory, which restricts itself to physical causes and effects, chiropractic discourse can emphasize physiological functions and anatomical structures-based on the "holistic" assumption of an underlying spiritual force that physical manipulations are thought to affect. ${ }^{67}$ The reluctance of many chiropractors to rely exclusively on physical explanations of causality may account for the apparent incongruity between the relatively

\footnotetext{
${ }^{64}$ Donahue, "Trouble With Innate," 23.

${ }^{65}$ Michael M. Burgess, "Chiropractic Informed Consent," Journal of the Canadian Chiropractic Association 34, no. 1 (1990): 24-26; Richard Steinecke, "Informed Consent," Journal of the Canadian Chiropractic Association 40, no. 1 (1996): 43-46. Since the civil rights and consumer revolutions of the 1960s, "informed consent" has become a watchword as Americans insist upon their moral and legal rights to make autonomous choices based on the principles of personal autonomy and self-determination. According to theorists of informed consent, the ability to make choices autonomously requires substantial understanding of all material information-not only medical risks and benefits, but also factors bearing upon patients' "longrange goals and values," including religious commitments; Ruth $\mathrm{R}$. Faden, Tom $\mathrm{L}$. Beauchamp, Nancy M. P. King, A History and Theory of Informed Consent (New York: Oxford University Press, 1986), 303.

${ }^{66}$ Albanese, Republic of Mind and Spirit, 5-6.

${ }^{67}$ John R. Platt, "Strong Inference," Science 146, no. 3642 (October 16, 1964): 347-53; Linda L. Barnes and Susan S. Sered, eds., Religion and Healing in America (New York: Oxford University Press, 2005), 22.
} 
modest aim of physically realigning nerve pathways and the chiropractic claim that doing so can prevent or treat many, if not all, diseases. ${ }^{68}$

In fact, when writing for each other and for patients who affirm chiropractic philosophy, many modern chiropractors do not hesitate to augment physiological rationales with harmonial explanations of the efficacy of adjustments. The historian J. Stuart Moore noted in 1993 that "chiropractic journals are full of neofundamentalist appeals for 'Revival in Chiropractic' which embrace the old-time views.... This strong harmonial resurrection within chiropractic orients these chiropractors to the Palmer legacy and focuses on differences rather than similarities with orthodox medicine."69 In confirmation of Moore's conclusion and the results of the Ohio survey, browsing through peer-reviewed journals, commercial magazines, and books published by chiropractors representing a variety of professional organizations from 1998 to 2009 yields a wealth of texts that quote appreciatively from the Palmers, personify Innate Intelligence, and emphasize the philosophical distinctiveness of chiropractic relative to biomedicine. Such texts regularly conceptualize Innate Intelligence in explicitly spiritual terms, reminding practitioners and patients of the "power of your inner spirit, soul or innate intelligence," since "we do not only consist of flesh and blood, but also of a soul and spirit. It is these intangible and unseen components that are often overlooked as potential interferences with our innate gift to be well." ${ }^{70}$ Innate Intelligence is envisioned as a spiritual agent who acts intentionally on the physical body to produce health; thus, if the chiropractor only makes "certain that the adjustment is given correctly ... innate will step in and do the rest," since "Innate intelligence ... already has the intention and control of all the components needed" for the "expression of health."71 In his "Chairman's Message," Edward Maurer writes in the Journal of the American Chiropractic Association in 1998 that

\footnotetext{
${ }^{68}$ Palmer, Chiropractor's Adjuster, 19; American Chiropractic Association, "Policy Statement"; International Chiropractors' Association, "11 Common Questions about Chiropractic" (n.d.), qtd. in Raso, "Alternative" Healthcare, 148-49. The Palmers taught that subluxations are behind every disease; although modern chiropractors have backed away from the theory of singular causation, according to the Ohio survey (p. 50), 10.9\% of chiropractors believe that subluxations contribute to $100 \%$ of visceral ailments; the mean response was that subluxations contribute to $62.1 \%$ of diseases.

${ }^{69}$ Moore, Chiropractic in America, 148.

${ }^{70}$ Timothy J. Gay, "Why Are You where You Are?" The Chiropractic Journal: A Publication of the World Chiropractic Alliance (June 2007), http://www.worldchiropracticalliance.org/tcj/2007/ jun/n.htm (accessed December 14, 2007); David Harper, "The Chiropractic Story," Natural Health Education Journal 11, no. 3 (winter 2007): 19 (emphasis in original).

${ }^{71}$ Krik Eriksen, Roderic P. Rochester, and John F. Grostic, Orthospinology Procedures: An Evidence-Based Approach to Spinal Care (Philadelphia: Wolters Kluwer Health/Lippincott Williams \& Wilkins, 2007), 279; Warren I. Hammer, Functional Soft-Tissue Examination and Treatment by Manual Methods (Sudbury, Mass.: Jones and Bartlett, 2007), 427.
} 
chiropractic is "steeped in philosophy" and that this philosophy "always adheres to the basic premise of universal or innate intelligence." Articles in other issues of the same journal published as recently as 2009 assert the consonance of the premise of Innate with other harmonial alternatives, such as Ayurvedic medicine, acupuncture, and tai chi chuan. ${ }^{72}$ Similarly, chiropractor Mike Reid elaborates on the spiritual meanings of Innate in a 2007 article in The Chiropractic Journal: A Publication of the World Chiropractic Alliance:

We are spiritual beings who are a piece of an entire bigger picture with a purpose in life.... As chiropractors, we already know that the universal intelligence lies within us as innate intelligence, causes our heart to beat, digests our food, and allows us to think as free people.... We've got to get back into a vibrational alignment where limitations of thought don't exist... because when we're in a state of fear, worry, jealousy or hatred we vibrate at a different frequency that will not attract from the universe, but will repel from it, that which we want ... Listen to your innate.... Sit in a lotus position with your palms opened up. See yourself as one and the same with the universe. ${ }^{73}$

For Reid, chiropractic can be melded with practices (such as sitting in a lotus position) borrowed from other traditions that seek to restore rapport with universal energy. Although members of the ACA and WCA (a 5,000member organization of "straights") disagree with one another over the appropriate scope of chiropractic, they are alike in crafting public policy guidelines using the language of scientific reductionism, while reinforcing a harmonial philosophy through publications directed toward chiropractic practitioners and patients.

Responding to published pleas of mechanical chiropractors to shed the "dogma" of Innate in order to achieve medical legitimacy, harmonial chiropractors regularly publish calls for a "return to our roots of allowing the patients' innate intelligence to perform freely and without interference." One text after another begins with quotations from the Palmers and then affirms that "the philosophical basis of chiropractic is that the body is self-regulating and self-maintaining, directed by a vitalistic force called Innate Intelligence. ${ }^{74}$ In a 2006 article for The Chiropractic Choice: A Publication

\footnotetext{
${ }^{72}$ See, for example, "Chiropractic Approach to Pain Relief, Rehabilitative Care," Journal of the American Chiropractic Association 46, no. 6 (August 2009): 16.

${ }^{73}$ Mike Reid, "The Seven Laws of the Power of Attraction," The Chiropractic Journal: A Publication of the World Chiropractic Alliance (August 2007), http://www. worldchiropracticalliance.org/tcj/2007/aug/.htm (accessed December 14, 2007; emphasis in original).

${ }^{74}$ Mark A. Amos, "What Do Symptoms Mean to the Chiropractor?" Journal of Chiropractic Humanities 13, no. 13 (2006): 27.
} 
of the International Chiropractors Association, Christopher Passalacqua insists that "our philosophy is what fundamentally sets us apart from the rest of the healthcare industry. ... As chiropractors we believe that all healing comes from within, (above-down inside-out), we believe that there is a Universal Intelligence (Principle \#1) that gives rise to all things, including our body's Innate Intelligence. We believe that life is necessarily intelligent (Principle \#2) and there can be interruption to the transmission of Innate forces (Principle \#29) that would cause our bodies not to adapt." ${ }^{, 75}$ Re-articulations of chiropractic philosophy similar to Passalacqua's reverberate through a substantial body of articles endorsed by their inclusion in journals published by the major chiropractic organizations.

Part of the answer to the question of how chiropractic entered the cultural mainstream is that it developed as a tradition-in-tension within itself and that its discourses proved sufficiently malleable to present the profession to the public using both physical and spiritual vocabularies, in turn or simultaneously, depending upon the goals of the individual chiropractor or professional organization speaking and the audiences they wished to address.

\section{The Christianization of Chiropractic}

One mark of chiropractic's arrival into the American cultural mainstream was its general acceptance, by the 1990s, in most avowedly "Christian" subcultures, despite the antipathy of chiropractic's founders toward Christianity and the mistrust of many early twentieth-century conservative Christians toward the harmonial assumptions of chiropractic philosophy. Since the first century, Christian practice has contained within it twin impulses: appropriation of "non-Christian" means for "Christian" purposes, and boundary-setting or proscription of particular beliefs and practices as inherently corrupt and corrupting. ${ }^{76}$ Which specific practices fall in or out of favor at a given time or place depend upon a variety of cultural and historical as well as religious factors. As historian R. Laurence Moore points out, "from somebody's point of view, all systems of thought ... are tainted with occult associations," and charges of heresy often reveal at least as much about those making the charges as about those censured. ${ }^{77}$ Chiropractic developed in America alongside a variety of metaphysical movements - most prominently Christian

\footnotetext{
${ }^{75}$ Christopher Passalacqua, "Advancement or Decline? Still Untold, Yet Ever Telling," The Chiropractic Choice: A Publication of the International Chiropractors Association 5, no. 2 (April 2006): 21.

${ }^{36}$ For the capacity of religions to proscribe as well as prescribe practices, see Thomas A. Tweed, Crossing and Dwelling: A Theory of Religion (Cambridge, Mass.: Harvard University Press), 6.

${ }^{77}$ Moore, “Occult Connection?" 136.
} 
Science, New Thought, Spiritualism, and Theosophy-that theologically conservative Christians tended to lump together in a common category of illegitimacy. Since chiropractic attracted relatively few adherents in its early years, Christian critics did not often single out the movement. Instead, they folded it in within their general denunciations of "non-Christian" metaphysics while they responded more systematically to the largest metaphysical movements that, because of the size of their followings, were perceived as the gravest threats to orthodoxy. ${ }^{78}$ In typical fashion, a writer for the Pentecostal Latter Rain Evangel, William Hamner Piper, wrote a 1911 article on "Giving Heed to Seducing Spirits: The Alluring Deceptions of the Day." Piper grouped together and denounced all those metaphysical systems that, regardless of whether they aspired to revere a supreme being, failed, in his view, to place sufficient emphasis on historical and theological claims concerning the death and resurrection of Jesus of Nazareth: "There are many antichristian cults, chief among which may be mentioned Christian Science, New Thought, Theosophy and Spiritism.... and all the rest of these false isms are exactly the same in this one point, that you can believe all you like in the existence of a Supreme Being, just so you do not recognize the necessity of Jesus Christ and His blood as the only way to that Supreme Being." Piper further specified, "The conflict of the centuries is not whether there is a Supreme Being, but whether Jesus Christ is essential to our salvation, and I take a step further, and say that it is not simply on Jesus Christ as a man or a character, but as to whether His blood is essential to our salvation. This then is the very center of the fight."79 Identifying "Marks of Error" in 1962 for The Pentecostal Evangel, Michael P. Horban similarly grouped together and condemned metaphysical healing traditions that emphasized "physical culture, health, mental hygiene" without teaching that the "real problems of man are sin and death, and the divine remedy is Jesus Christ crucified and risen from the dead." ${ }^{80}$ Likewise, a 1977 article by Richard H. Bube, entitled "Pseudo-Science and Pseudo-Theology: (A) Cult and Occult" in the Journal of the American Scientific Affiliation, specifically mentioned chiropractic alongside yoga, acupuncture, Transcendental Meditation, Scientology, and Christian Science, all of which the author considered unscientific and unchristian-because all are "essentially unanimous in their rejection of the Biblical doctrine of the Trinity and of the

\footnotetext{
${ }^{78}$ Kerr and Crow, introduction to Occult in America, 6, argue that "chiropractic, now covered by medical insurance and federal income tax deductions, grew out of the same nineteenth-century 'occult-metaphysical tradition' that fostered transcendentalism, mesmerism, spiritualism, Theosophy, Christian Science, and New Thought."

${ }^{79}$ William Hamner Piper, "Giving Heed to Seducing Spirits: The Alluring Deceptions of the Day," Latter Rain Evangelical (October 1, 1911): 2.

${ }^{80}$ Michael P. Horban, "Marks of Error," The Pentecostal Evangel (December 9, 1962): 7.
} 
deity of Jesus Christ." ${ }^{\text {81 }}$ At issue in such critiques was not simply the question of whether use of "physical means," such as medicine, was compatible with faith in God for healing--although certain Christians did denounce medicine because of this concern; ${ }^{82}$ rather, metaphysical healing traditions faced the more pointed charge that they pursued physical and spiritual harmony with God or the cosmos while denying the necessity of repentance from sin and trust in the atoning death and resurrection of Jesus Christ.

Chiropractors who sought acceptance within a perceived Christian "mainstream," like proponents of metaphysical healing traditions such as Christian Science or New Thought, responded to charges of heterodoxy by insisting upon their "Christian" identity. Although comprehensive data are unavailable, several surveys suggest that a substantial number-perhaps as many as $88 \%$ - of chiropractors have come to self-identify as Christian. ${ }^{83}$ Promotional materials directed at Christian audiences explain chiropractic philosophy in terms calculated to minimize perceived tension with Christianity. In "A Christian Concept of Chiropractic Philosophy" (1952)dedicated in a handwritten note "to Dr. B. J. Palmer, leading chiropractor and Chiropractic Philosopher, from his appreciative pupil"-H. L. McSherry

\footnotetext{
${ }^{81}$ Richard H. Bube, "Pseudo-Science and Pseudo-Theology: (A) Cult and Occult," Journal of the American Scientific Affiliation 29, no. 1 (March 1977): 22-28.

${ }^{82}$ For one such anti-medical statement, see Alexender Dowie, Doctors, Drugs and Devils, or, the Foes of Christ the Healer (Zion City, Ill., 1901). Some evangelicals included divine healing in their catalogues of un-Christian practices, for example, J. M. Buckley, Faith-Healing, Christian Science and Kindred Phenomena (New York: Century, 1892).

${ }^{83}$ Moore, Chiropractic in America, 189-90. Since no comprehensive survey data exists, Moore pieces together several studies. A series of biographical sketches of Oklahoma chiropractors published in 1930 gives the religious affiliations of 50 out of the 112 practitioners listed: 11 Baptists, 11 Methodists, 8 Christian/Church of Christ members, 8 Presbyterians, 4 Methodist Episcopals, 2 Catholics, 2 Quakers, 1 Lutheran, 1 Nazarene, 2 from the Reorganized Church of Jesus Christ of Latter-Day Saints, and 2 who attended Phillips Christian University "preparatory for Evangelistic work." Moore notes that many of the same individuals also "belonged to the Masons, Shriners, and other fraternal bodies." A study of the religious affiliations of chiropractors in Missouri for 1972 concluded that out of 58 practitioners, $40(70.7 \%)$ identified themselves as Protestant, $10(17.2 \%)$ as Catholic, 2 (3.4\%) claimed other religious backgrounds, and $5(8.7 \%)$ had no religious affiliation. Who's Who in Chiropractic (1980) includes 875 entries: no religious affiliation is listed for $310(35.4 \%)$ of the individuals; Catholics number 103 (11.8\%); Protestants account for 421 (48.1\%); 23 (2.6\%) are identified as Jewish; and $18(2.1 \%)$ identify other religious backgrounds, including 1 self-described "Unitarian Atheist"; Harry Gallagher, History of Chiropractic: A History of the Philosophy, Art and Science of Chiropractic and Chiropractors in Oklahoma (Guthrie, Okla.: William E. Welch \& William H. Pattie, 1930), 107-76; Phylis Lan Lin, "The Chiropractor, Chiropractic, and Process: A Study of the Sociology of an Occupation" (PhD diss., University of Missouri-Columbia, 1972), 54; Fern Lints-Dzaman, Sidney Scheiner, and Larry Schwartz, eds., Who's Who in Chiropractc, 2nd ed. (Littleton, Colo.: Who's Who in Chiropractic International Publishing, 1980), 23-265. These findings are consonant with surveys of the religious identities of the total U.S. population; for example, the 2008 American Religious Identification Survey (ARIS) found that $76 \%$ of Americans self-identify as Christians, down from $86 \%$ in 1990; Barry A. Kosmin and Ariela Keysar, ARIS 2008 Summary Report (Hartford, Conn.: Trinity College, March 2009).
} 
remains silent about Palmer's explicitly anti-Christian sentiments, instead arguing that chiropractic is not a "religion, yet its philosophy resembles Christian theology." ${ }^{, 84}$ Recognizing the authority of Christianity in American culture and identifying clergy as strategic allies against a powerful medical establishment, McSherry courts clerical support. Since chiropractors and clergy both strive to keep people adjusted to the created order, McSherry reasons, they are natural allies: "Through prayer the clergyman strives to keep man's soul in tune with the Infinite! By manual vertebral adjustment, the chiropractor frees the nerve paths to keep man's body in tune with the same Infinite Intelligence." Playing upon Christian suspicions of modern science, McSherry denounces the "evil effects" of medicine as "MED-Isin,'-and sin in any form we are definitely against!" McSherry forthrightly appeals to Christian clergy: "may we merit your sincere co-operation in our efforts to spread our gospel of health to all the world." Remaining vague about the meanings of Infinite Intelligence and sin, McSherry glosses the distinction between the "gospel" of chiropractic and Christianity, subtly recasting chiropractic terminology to make it accord with Christian theology.

The best organized national association of Christian chiropractors, the Christian Chiropractors Association (CCA), advertises its evangelical selfidentity. The CCA formed as a student group at the Palmer School of Chiropractic in 1951 under the aegis of evangelical campus ministry InterVarsity Christian Fellowship, adding one thousand members nationwide by $2006 .{ }^{85}$ An official "Statement of Faith" identifies the CCA as "conservative in theology," embracing the "cardinal essentials of the historic Christian faith," with special emphasis on world mission: "sending Christian Chiropractors out to many whitened harvest fields with the Gospel of Christ and chiropractic before Jesus comes." ${ }^{, 86}$ In a linguistic flourish reminiscent of the Palmers' cosmic vision reworked into the language of evangelicalism, the CCA presents chiropractic as a Gospel parallel nearly equal to the New Testament.

CCA promotional materials solicit Christian clients by addressing evangelical insecurities about their cultural position relative to secular medical science and the rapidly growing phenomenon of Charismatic and

\footnotetext{
${ }^{84}$ H. L. McSherry, "A Christian Concept of Chiropractic Philosophy," Journal of the National Chiropractic Association (May 1952): 5, 13, 10.

${ }^{85}$ Glenn M. Hultgren, Against All Odds ... But God!: An Account of the Activities of the First Fifty Years of the Christian Chiropractors Association (Fort Collins, Colo.: Christian Chiropractors Association, 2003), 8; CCA headquarters, telephone conversation with the author, March 16, 2006.

${ }^{86}$ Christian Chiropractors Association, "Statement of Faith" (Fort Collins, Colo.: Christian Chiropractors Association, [1988?]), qtd. in Moore, Chiropractic in America, 190; Christian Chiropractors Association, "Statement of Faith and Mission Statement," http://www. christianchiropractors.org/state.htm (accessed Sept 19, 2005).
} 
Pentecostal Christianity-a diffuse subculture within evangelicalism that includes as much as $23 \%$ of the U.S. population. ${ }^{87}$ Writing in the 2000 s, Glenn Hultgren, official spokesperson for the CCA, contrasts chiropractic to the "reductionistic or mechanistic philosophy" of biomedicine and the alleged faith healings that Charismatic "Christians" perform by the power of "Satan and his false spirits," while preaching "powerful messages in pulpits around the world, drawing huge followings, performing miracles of healing, casting out devils, (slaying in the spirit) and telling the people that it is all in the name of the Lord." ${ }^{88}$ Having identified non-Charismatic evangelicals and chiropractors as allied by a shared spirituality against common opponents, Hultgren assuages potential evangelical concerns about chiropractic's vitalistic philosophy by recasting the concept of Innate as rooted in the Bible. In classic evangelical style, Hultgren invokes a series of biblical references to argue that Innate is "part of the immaterial nature which God breathed into man when He called man a living soul. (Gen. 2:7; Acts 17:25; Ps. 36:9; Job 33:4)." Heightening his credibility by positioning himself as critical of the Palmers for "deify[ing] the vitalistic nature," Hultgren coins the phrase "theistic vitalism" to merge the concept of Innate Intelligence with the Bible's view of a creator God. Hultgren deflects evangelical criticism by acknowledging that the Palmers held unorthodox religious views and insisting that his own beliefs are theologically conservative. Although a relatively small percentage of Christian chiropractors belong to the CCA, the organization's rhetorical strategies reflect a broader impulse to represent chiropractic philosophy and Christianity as complementary.

As chiropractors sought Christian clients, changing cultural understandings of pain prepared audiences to respond favorably to chiropractic appeals. Until the mid-nineteenth century, Christian clergy often identified somatic pain as chastisement for sin or as a means of sharing in the sufferings of Christ. ${ }^{89}$ When physicians prescribed "heroic" medical interventions-which were physically excruciating and financially devastating-Calvinist clergy urged parishioners to submit to their doctors as if submitting to God. ${ }^{90}$ As many lay Protestants revolted against Calvinism, they re-envisioned pain as

\footnotetext{
${ }^{87}$ Corwin E. Smidt, Lyman A. Kellstedt, John C. Green, and James L. Guth, "The Spirit-Filled Movements in Contemporary America: A Survey Perspective," in Pentecostal Currents in American Protestantism, ed. Edith L. Blumhofer, Russell P. Spittler, and Grant A. Wacker (Urbana: University of Illinois Press, 1999), 120.

${ }^{88}$ Glenn M. Hultgren, "Alternative Therapies: Making a Difference through Spiritual Evaluation," (Christian Chiropractor's Association, n.d.), 7, 2, 5-6, http://www. christianchiropractors.org/altern pagel.htm (accessed September 16, 2005).

${ }^{89}$ Heather Curtis, Faith in the Great Physician: Suffering and Divine Healing in American Culture, 1860-1900 (Baltimore: Johns Hopkins University Press, 2007), 2.

${ }^{90}$ Martin S. Pernick, A Calculus of Suffering: Pain, Professionalism, and Anesthesia in Nineteenth-Century America (New York: Columbia University Press, 1985), 7-8, 13-14, 56.
} 
morally evil, sent by the devil rather than God, and rejected severe medical regimens in favor of the body's "natural" restorative powers. Meanwhile, biomedicine reinterpreted pain not as a spiritual malady, the cause of which demands explanation, but merely as a physical sensation-one that most people want to avoid. ${ }^{91}$ Developments in anesthesia made freedom from pain appear attainable, but medicine's failure to eradicate pain encouraged therapeutic experimentation. ${ }^{92}$ People who no longer felt constrained by theological or medical interpretations of pain as spiritually or physically beneficial were, in the words of historian Robert Fuller, "understandably concerned with the relief of pain." 93 As pain lost its compensatory association with a higher spiritual purpose, the suffering produced by pain intensified, increasing the urgency of finding relief. ${ }^{94}$ Lacking assurance that pain means something and is therefore "real," doctors who failed to locate a physiological cause for much chronic pain became less likely to take complaints seriously, adding to the experienced suffering. ${ }^{95}$ The driving question in evaluating pain relief methods shifted from "what does it mean?" to "does it work?"

The desire for therapeutic benefits led some Christians to explore metaphysical healing traditions such as Christian Science, while others tried chiropractic. D. D. Palmer's first clerical apologist was the Presbyterian Samuel H. Weed, the same minister credited with naming the profession. At first dismissing Palmer as an unorthodox charlatan, Weed reversed his opinion when his daughter and then he experienced pain relief subsequent to Palmer's treatments. ${ }^{96}$ Preaching Palmer's funeral sermon in 1913, Weed sought to persuade his audience that chiropractic and Christianity converged. The term "Innate," Weed explained, appears in the New Testament. James 1:21 instructs the Christian to "receive with meekness the engrafted word, which is able to save your soul."97 The phrase "engrafted word" could instead, according to Weed, be translated as Innate. Similarly, 1 Peter 5:10

\footnotetext{
${ }^{91}$ Morris, Culture of Pain, 5.

${ }^{92}$ Early resistance to the use of anesthesia (introduced in 1846 , but not used universally until the 1880 s) came not only from clergy who envisioned pain as sent by God, but also from advocates of nature cures who worried that artificial insensitivity to pain would impede the restoration of harmony between individuals and nature.

${ }^{93}$ Fuller, Alternative Medicine, 80; see also Judith Walzer Leavitt, Brought to Bed: Childbearing in America, 1750 to 1950 (New York: Oxford University Press, 1986), 117.

${ }^{94}$ Ariel Glucklich, Sacred Pain: Hurting the Body for the Sake of the Soul (New York: Oxford University Press, 2001), 62.

${ }^{95}$ Elaine Scarry, The Body in Pain: The Making and Unmakang of the World (New York: Oxford University Press, 1985), 6.

${ }^{96}$ Whorton, Nature Cures, 168.

97"Memorial Service: In Respect to Dr. D. D. Palmer, Discoverer of Chiropractic, October 23, 1913, at the P.S.C.," The Chiropractor 9 (December 1913), reprinted in B. J. Palmer, History Repeats (Davenport, Iowa: Chiropractic Fountain Head, 1951), 158-59.
} 
uses the word "adjustment": "But the God of all grace, who hath called us into his eternal glory by Christ Jesus, after that ye have suffered a while, make you perfect, establish, strengthen, settle you." The word translated "perfect" means "adjust" in the original Greek, Weed argued, indicating that Jesus performed the ultimate spiritual adjustment. Weed used biblical passages to demonstrate the congruence of chiropractic and Christianity, even when doing so required hermeneutical gymnastics. ${ }^{98}$ Chiropractic attracted a thin stream of clerical defenders throughout the twentieth century. For instance, the Baptist minister Ross Lyon in 1977 employed a series of biblical quotations to compare chiropractic adjustments with the "great spiritual adjustment [which] came on that cross." ${ }^{.99}$ Reverend George Boyajian, in an article written in the 1950 s and posted on the CCA website in the 2000 s, affirmed that as a Christian minister he had "recommended Chiropractic as developed by the Palmer School to many people."100 Such clerical endorsements of chiropractic were, however, rare for most of the twentieth century.

The desire for pain relief was a necessary but insufficient condition for chiropractic's widespread acceptance among conservative Christians. Heirs to the Protestant Reformation's emphasis on the priesthood of all believers, American evangelicals frequently insisted that laity as well as clergy must use the Bible to evaluate the legitimacy of every practice, regardless of its benefits, that might have a bearing on the state of their souls. ${ }^{101}$ Having abandoned the notion that Christians should harm the body to heal the soul, evangelicals remained anxious about harming the soul to heal the body. ${ }^{102}$ To avoid this perceived danger, they categorized therapies as "legitimate" or "illegitimate." Since the 1970s, the term "New Age" has functioned in popular evangelical culture as a code word for anything that a spokesperson evaluates as illegitimate for Christians. ${ }^{103}$ The New Age label served to group together pejoratively diverse beliefs and practices that evangelicals viewed as expressing "heretical," "Eastern," "pantheistic," "panentheistic," and "unscientific" ideas of tapping into spiritual energy in ways unauthorized by the Bible. As chiropractic gained cultural visibility by winning legal

\footnotetext{
${ }^{98}$ Moore, Chiropractic in America, 100.

${ }^{99}$ R. D. Lyon, "Chiropractic Philosophy and the Bible," Today's Chiropractic (March/April 1977): 31; cf. J. D. Guengerich, Chiropractic and the Bible: The One as a Means of Correcting the Abnormal Condition of the Body and the Other as a Means of Correcting the Condition of the Soul (Centralia, Mo.: J. D. Guengerich, 1917), 36.

${ }^{100}$ George Boyajian, My Views on Chiropractic (Covington, Ky.: James N. King, [1950s?]), http://christianchiropractors.org/boyaj.htm (accessed March 16, 2006).

${ }^{101}$ Candy Gunther Brown, The Word in the World: Evangelical Writing, Publishing, and Reading in America, 1789-1880 (Chapel Hill: University of North Carolina Press, 2004), 3.

${ }^{102}$ Glucklich, Sacred Pain, 4-7.

${ }^{103}$ For a typical example, see an article published in the journal of the British Christian Medical Fellowship by George Smith, "Chiropractic," Triple Helix (Winter 2005): 10, in which Innate is coded as "akin to the New Age pantheistic view of God."
} 
protection and insurance coverage, conservative Christians debated whether chiropractic should be classified as New Age or scientific and, hence, religiously neutral and available for legitimate appropriation. Isolating a single, unified "evangelical" position on chiropractic, or most other issues, is an elusive goal, but what is significant in this context is that self-identified evangelicals came to frame their evaluations of chiropractic largely in terms of "New Age" illegitimacy on the one hand, or "scientific" legitimacy on the other. ${ }^{104}$

With the rise of the holistic healthcare movement, evangelical consumers confidently classified many alternative therapies as New Age and thus illegitimate, but they felt less certain about the status of chiropractic. Selfavowed evangelical "watchdogs"-groups that envision themselves as exposing heretical threats to Christian orthodoxy - have been relatively restrained in their critiques of chiropractic. Ruth Gordon, an author for the Internet-based "Watchman Fellowship: A Ministry of Christian Discernment" (2000), warns a popular readership that chiropractic is "easily integrated with many other new age therapies." 105 What is notable about this text is how Gordon quotes another evangelical publication, John Ankerberg and John Weldon's Can You Trust Your Doctor? The Complete Guide to New Age Medicine and Its Threat to Your Family (1991)-out of context-to emphasize that there is a category of "legitimate chiropractic," that which is "within the realm of modern medical scientific practice." the next sentence of Ankerberg and Weldon's text, which argues that the "great majority" of chiropractors fall outside the category of legitimacy. Interestingly, neither Gordon nor Ankerberg and Weldon express any sense of tension between the materialistic philosophical assumptions underlying biomedicine and a Christian worldview. ${ }^{107}$ Although Gordon implicitly disagrees with Ankerberg and Weldon about where most chiropractors should be classified, they all agree in contrasting the category of New Age illegitimacy with that of "modern medical scientific" legitimacy.

\footnotetext{
${ }^{104}$ Christian Smith, Christian America? What Evangelicals Really Want (Berkeley: University of California, 2000).

${ }^{105}$ Ruth Gordon, "Chiropractic Medicine - Science or Science Fiction?" The Watchman Expositor 9, no. 7 (Watchman Fellowship: A Ministry of Christian Discernment, 1992), http:// www.watchman.org/na/chirol.htm (accessed September 20, 2005).

${ }^{106}$ John Ankerberg and John Weldon, Can You Trust Your Doctor? The Complete Guide to New Age Medicine and Its Threat to Your Family (Brentwood, Tenn.: Wolgemuth and Hyatt, 1991), 206.

${ }^{107}$ Balanced against evidence of evangelical suspicions of biomedical science presented elsewhere in this essay, it appears that there is some ambivalence toward modern medicine within evangelical culture: theological concern about the philosophical assumptions of scientific naturalism and cultural insecurity about the authority of medical professionals, but also a desire for the practical benefits and prestige of science.
} 
Evangelical assessments of chiropractic focused on whether it was guilty by association with other practices that evangelicals typically classified as New Age. A popular guide to New Age Medicine (1987), issued by evangelical publisher InterVarsity Press, advises Christians to avoid the "minority contingent of chiropractors who promote acupressure, applied kinesiology and other questionable pursuits."108 The authors find it "particularly unsettling to see members of the Christian community having their energies balanced by chiropractors and other therapists who claim a Christian commitment and who feel that they are not involved in any questionable practices. These practitioners may claim that Ch'i, yin and yang, and meridians are neutral components of God's creation (similar to electricity and radio waves), available for anyone to use; but they ignore the roots of these ideas." Asserting that "classical chiropractic theory" is similarly rooted in the premise that "spinal manipulations allow the Innate to flow more easily through the nervous system," the authors differentiate modern chiropractic from apparently "neutral," yet "questionable" practices that they condemn based on a generalized, popular understanding of Taoist, Buddhist, and Ayurvedic healing traditions. Historian of chiropractic J. Stuart Moore argues that "evangelicals seem to be unaware that, even though the Palmer ideology has certain affinities to Eastern mysticism with its direction of unseen life forces and energies, it is more clearly a popular manifestation of the Western harmonial tradition." 109 Rather than commenting favorably or unfavorably on chiropractic's harmonial philosophy, evangelicals zeroed in on the question of whether chiropractic was severable from practices coded as "Eastern," "New Age" religiosity.

Having identified chiropractic as separable from religious practices that evangelicals regarded as "questionable," two steps remained to exonerate chiropractic from potential charges of illegitimacy: disentangling "physical" techniques from "spiritual" rationales, and validating techniques as "scientific" based on perceived efficacy. The Biblical Guide to Alternative Medicine (2003), written by popular evangelical author Neil Anderson and a medical doctor, Michael Jacobson, downplays the significance of chiropractic philosophy. Acknowledging that D. D. Palmer "spoke of the 'innate' as a healing force," the authors qualify, "to what degree he ascribed a spiritual dimension to the innate is not clear."110 The sparsely footnoted text concludes that "a chiropractor who practices pure chiropractic

\footnotetext{
${ }^{108}$ Paul C. Reisser, Teri K. Reisser, and John Weldon, New Age Medicine: A Christian Perspective on Holistic Health, rev. \& expanded ed. (Downers Grove, Ill: InterVarsity Press, 1987), 3-4, 94, 37.

${ }^{109}$ Moore, Chiropractic in America, 204.

${ }^{110}$ Neil T. Anderson and Michael Jacobson, The Biblical Guide to Alternative Medicine (Ventura, Calif.: Regal Books, 2003), 149, 152-53.
} 
musculoskeletal medicine-focusing on adjustment of the spine-is operating purely in the physical realm." The text implies that as long as a technique is "purely" "physical," and hence classifiable as "musculoskeletal medicine," the practice can be unmoored from a potentially suspect "spiritual dimension." Similarly, Internet-based "Let Us Reason Ministries" concludes that "out of all the new age practices that are used today this [chiropractic] is one of the few that can be practiced apart from its Occultic energy philosophy. This can only be done when physically adjusting your spine excluding the occult view that is attached to it." 111 The authors do not specify how physical techniques and spiritual views can be disentangled, yet they appear confident that doing so is relatively easy. What sets chiropractic apart from other "occult" practices is that it works to relieve pain: "we should be careful not to call ALL chiropractic care occult or quackery. Many Chiropractors do provide temporary and even permanent relief from pain, as structural misalignments are corrected and nerves are relieved." The authors (who do not concern themselves with reviewing clinical studies that assessand in many instances discount - the effectiveness of spinal manipulation in relieving back pain or other conditions) absolve chiropractic of the irreligious label of "occult" and the unscientific label of "quackery" because they believe physical adjustments to be effective in relieving pain. ${ }^{112}$

Regardless of whether chiropractic is actually effective, its widespread acceptance among conservative Christians as legitimate science rather than New Age spirituality hinges upon perceived efficacy in relieving pain. Heirs of Enlightenment empiricism, evangelicals assume that God created the world using natural laws; thus, empirical demonstration of a method's effectiveness provides evidence of its conformity to God's created order. Following this line of reasoning, the CCA issued a "New Age Position Statement," explaining that Christian chiropractors differ from "New Age holistic healers" by using methods that are effective because they "conform to God's created order."113 Despite often making strenuous efforts to avoid New Age therapies, evangelicals have tended to follow a circular train of assumptions: science provides empirical evidence of God's created order; any technique that is effective is scientific; if scientific, then religiously neutral; if religiously neutral, then available for legitimate use by Christians. Thus, Christian chiropractors successfully deflected suspicions of New Age associations through simple speech acts of denial and affirmation: they are not New Age; they are scientific. For many evangelical healthcare

\footnotetext{
${ }^{111}$ Let Us Reason Ministries, “Chiropractic," http://www.letusreason.org/NAM33.htm (accessed September 19, 2005).

${ }^{112}$ E. Ernst and P. Canter, "A Systematic Review of Systematic Reviews of Spinal Manipulation," Journal of the Royal Society of Medicine 99 (April 2006): 189-93.

${ }^{113}$ Hultgren, "Alternative Therapies," 5.
} 
consumers, visiting a doctor of chiropractic is much like seeing a medical doctor. Although evangelicals insist that the "truth" of every practice must be judged by the Bible, in the complex negotiations that mark lived experience, empirical observation often reshapes theology. Evangelical apologetics for chiropractic as effective do not tackle the question of whether a system of physical manipulations can be logically separated from metaphysical rationales for why adjustments work. Perhaps ironically, given the sometimes strident efforts of evangelicals to defend orthodoxy, claims of effectiveness inhibit, instead of stimulate, theological reflection about chiropractic philosophy. ${ }^{114}$

Word-oriented evangelicals sharply distinguish theological beliefs, which must be guarded against contamination, from scientific techniques, which they assume to be morally neutral. ${ }^{115}$ Studies show that some individuals who first visit a chiropractor because they want the practical benefits of physical manipulations have, in the language of sociologists Meredith McGuire and Debra Kantor, "opened the door" to journey into a variety of metaphysical philosophies. ${ }^{116}$ Some evangelicals overcome suspicions of New Age therapies after a favorite chiropractor employs acupuncture or refers them to an herbalist. The historian Robert Fuller has argued provocatively that "Americans' involvement with unorthodox medical practices often leads them to a variety of unorthodox religious beliefs." 117 Pragmatic healthcare decisions can result in de facto religious choices that, in a culture marked by therapeutic experimentation, may contribute to a fundamental reorganization of American religious life.

\section{Combining Chiropractic, Medicine, and Prayer FOR DIVINE HeALING}

Given scholarly interest in the diversification of the American religious landscape, the blurring of boundaries between metaphysical and Christian practices merits further attention. ${ }^{18}$ Considering that for much of the twentieth century chiropractic and evangelical Christianity were widely perceived as occupying outposts on opposite sides of a philosophical chasm,

\footnotetext{
${ }^{114}$ For a discussion of how evangelicals blend pragmatism, enthusiasm for "science," and antiintellectualism, see Mark A. Noll, The Scandal of the Evangelical Mind (Grand Rapids, Mich.: Eerdmans, 1994), 12.

${ }^{115}$ Brown, Word in the World, 244.

${ }^{116}$ Meredith B. McGuire and Debra Kantor, Ritual Healing in Suburban America (New Brunswick, N.J.: Rutgers University Press, 1988), 29.

${ }^{117}$ Fuller, Alternative Medicine, 4.

${ }^{118}$ R. Marie Griffith, Born Again Bodies: Flesh and Spirit in American Christianity (Berkeley: University of California Press, 2004), x; Albanese, Republic of Mind and Spirit, x.
} 
it is striking how many Americans today demonstrate allegiance both to chiropractic and to evangelicalism. For Charismatic and Pentecostal Christians, the embrace of chiropractic is doubly perplexing given nationally circulated Christian chiropractic position statements that condemn Charismatic "faith healing" as satanically inspired. ${ }^{119}$ Yet symptomatic of a therapeutic culture, alignments of beliefs, practices, and loyalties are readjusted as those in need of healing combine philosophically diverse approaches in an effort to find what works for them. The relative availability and affordability of healing alternatıves has created an atmosphere of "medical pluralism," as historian James Whorton terms it, in which patients draw from a range of therapies, "achieving at last an 'essential unity' of medical truth." 120 When pain relief becomes the driving imperative, therapeutic relativism is frequently embraced by people who would strenuously resist charges of theological relatıvism.

Christians who need healing often combine chiropractic with medicine and prayer for divine healing of the same condition. A study of CAM usage in a rural Illinois community found that $63 \%$ had tried at least one alternative, and $90 \%$ of CAM users combined at least two approaches - among the most common of which were chiropractic and prayer. $66 \%$ of CAM users went to a chiropractor, and $58 \%$ used "prayer/faith healing." 121 In a study of fibromyalgia patients receiving conventional medical therapies at the Mayo Clinic, $47 \%$ used chiropractic and $45 \%$ used "spiritual healing (prayers)." Although, frustratingly, neither study reported the number of subjects who used both chiropractic and prayer, or the specific expectations that patients brought to-or took from-these healing encounters, the high usage rates of both therapies alongside conventional medicine suggest that many of the same individuals integrated philosophically divergent approaches.

Despite numerous recent studies evaluating the combination of intercessory prayer with conventional medicine, scholars have not investigated whether individuals combine Christian prayer for divine healing with chiropractic. ${ }^{123}$

${ }^{119}$ Hultgren, "Alternative Therapies," 7

${ }^{120}$ Whorton, Nature Cures, 24

${ }^{121} \mathrm{M}$ Herron and M Glasser, "Use of and Attitudes toward Complementary and Alternative Medicine Among Family Practice Patients in Small Rural Illınoıs Communities," Journal of Rural Health 19, no 3 (2003) 280

${ }^{122}$ Dietlind L Wahner-Roedler, Peter L Elkin, Ann Vincent, Jeffrey M Thompson, Terry H Oh, Laura L Loehrer, Jayawant N Mandrekar, and Brent A Bauer, "Use of Complementary and Alternative Medical Therapies by Patients Referred to a Fibromyalgia Treatment Program at a Tertiary Care Center," Mayo Clinic Proceedings 80, no 1 (2005) 55

${ }^{123}$ See, for example, H Benson, J A Dusek, J B Sherwood, P Lam, C F Bethea, W Carpenter, S Levitsky, P C Hill, D W Clem, M K Jain, D Drumel, S L Kopecky, P S Mueller, D Marek, S Rollins, and P L Hibberd, "Study of the Therapeutic Effects of Intercessory Prayer (STEP) in Cardiac Bypass Patients A Multicenter Randomized Tral of Uncertanty and Certainty of Receiving Intercessory Prayer," American Heart Journal 151, no 4 (2006) 934-42 
Such an inquiry illumines one important point of connection between evangelical and metaphysical practices as Americans in pain piece together therapeutic resources to meet practical needs. The present author supplemented a review of CAM studies with the collection and analysis of new data, gathered from written surveys and telephone interviews with individuals seeking prayer for healing. The author designed and distributed a four-page "Healing Survey" to more than 2,000 self-identified Christians who attended religious conferences conducted by an internationally prominent Charismatic group in Toronto, Ontario (August 17-20, 2005), Harrisburg, Pennsylvania (November 2-5, 2005), and St. Louis, Missouri (February 28-March 3, 2006). ${ }^{124}$ The organization trained and supervised prayer teams who articulated a shared theology of divine healing: a personal God supernaturally intervenes in the natural world to heal miraculously, in the name of Jesus of Nazareth, by the power of the Holy Spirit. The "pre" and "post" conference questionnaires included twenty-seven questions that asked subjects to describe any illness, pain, or disability for which they wanted to receive healing through prayer; medical and alternative medical or spiritual remedies they had tried or would consider trying in the future; and any healing they believed themselves to have experienced during the conference through prayer. Question nine on the pre-conference survey was worded: "Other than prayer, have you ever tried alternative medical or spiritual remedies for healing of this condition? Please circle one or more of the following: CHIROPRACTIC, MASSAGE, MEDITATION, ACUPUNCTURE, HERBAL, YOGA, REIKI, NATUROPATHY, HOMEOPATHY, THERAPEUTIC TOUCH, CHRISTIAN SCIENCE, NATIVE AMERICAN, UNITY, SANTERIA, CURANDEROS/AS, PSYCHIC, OTHER:

NOT SURE, NONE." Two hundred fifty-two individuals completed the surveys. Of 163 respondents who indicated that they hoped to receive divine healing, $43(26.4 \%)$ reported having visited a chiropractor. In 55 follow-up interviews, a similar proportion, $20(36.4 \%)$, volunteered that they had received chiropractic adjustments. ${ }^{125}$ These percentages are consistent with studies of the general population that report $30 \%$ chiropractic usage rates

\footnotetext{
${ }^{124}$ This study received IRB approval from Saint Louis University (\#13946) and Indiana University (\#06-11383). The surveys were added to the registration packets distributed by the sponsoring organization to all conference participants. Each survey packet included a Study Information Sheet. The surveys were completed anonymously, but informants were given the option of completing a contact card if they wished to participate in a follow-up telephone interview. Demographic information collected through the survey indicated that participants represented diverse gender, age, racial/ethnic, educational, and income groups; most selfidentified as Charismatic, Pentecostal, and/or evangelical Protestants or Catholics.

${ }^{125}$ The telephone interviews followed a semi-structured format. I asked open-ended questions and listened to informants' answers without comment. Most respondents who mentioned receiving chiropractic treatments volunteered this information before I asked about it. I asked informants who did not initiate a discussion of chiropractic whether they had ever tried any form of alternative healthcare, and I reminded them of a few of the approaches listed in question nine
} 
among Americans experiencing back pain, suggesting that belief in divine healing makes it neither more nor less likely that one will visit a chiropractor. ${ }^{126}$

Christians surveyed indicated a general acceptance of chiropractic as complementary to prayer for divine healing. Out of 55 individuals interviewed, $22(40 \%)$ reported that they had either visited a chiropractor or would consider doing so. Only one person noted that she had discontinued treatment for religious reasons: "I was struggling with back pain and was actually seeing a chiropractor rather frequently. And I was just convicted that I was really having more faith in the chiropractor meeting my need ... I decided I was going to trust the Lord for my healing rather than the chiropractor and it was when I made that decision that my back pain went away and I have not been plagued with it since." This woman suggested that she had invested such a high level of trust in her chiropractor, whom she saw "rather frequently," that she found herself placing less trust in God to heal her. Similarly one man, who completed a questionnaire but did not provide his contact information for a follow-up interview, claimed that God had miraculously healed him of terminal cancer seven years before. He considered medical doctors unproblematic and continued going to them for "surveillance." But he wrote "no" several times across the section of the questionnaire that asked about alternative remedies, implying his sense that metaphysical practices could not be incorporated within evangelical theology: "No-God gets all the glory." This respondent distinguished between medical treatment, which he considered a legitimate means through which God can heal, and metaphysically premised alternatives, which he perceived as illegitimate because they pointed to an ultimate source of healing other than the Christian God.

Other evangelicals interviewed exhibited a similar propensity for boundarysetting-identifying certain therapies as congruent with orthodoxy and others as tainted with heretical implications. Many interviewees considered chiropractic more acceptable than other metaphysical alternatives; given an assumptive binary that practices are either scientific or New Age, perceived efficacy in relieving pain made chiropractic philosophy seem less salient. One individual singled out chiropractic as one of the only healing alternatives that Christians could legitimately employ. This man reported that chiropractic was the only alternative on the survey that he did not have

of the survey, including chiropractic. This question in several instances elicited lengthy responses to which I listened without commentary.

${ }^{126}$ Daniel C. Cherkin and Frederick A. MacCornack, "Patient Evaluations of Low Back Pain Care from Family Physicians and Chiropractors," Western Journal of Medicine 150, no. 3 (1989): 351 . 
"enough reservations about that I'd just as soon not do. Most of the other things would be called New Age. I'm a Christian and I don't believe that they're avenues I should pursue. Chiropractic is, I wish I had a better understanding of how it's supposed to work, but it seems to work, and I'm willing to try that." This individual classified most alternative medicine as New Age, thus illegitimate, but he made an exception for chiropractic-despite feeling uneasy that he lacked understanding of its philosophy-because it seemed effective. Another respondent reported having tried acupuncture, but stated that she "wouldn't do that again." It had been painful and ineffective, and "I was in a different place in my life back then, and I am not sure that that is an approved way for a Christian to get healed." This woman had a strikingly more positive evaluation of chiropractic: "I have never been to a chiropractor. I know people who do go and they say that it helps them a lot. I guess I've never been led to do it. I don't think that it's something the church doesn't approve of. I think it's perfectly ok. I just haven't done it." In the absence of clerical disapproval and convinced of its efficacy, this individual felt comfortable classifying chiropractic as legitimate. Another interviewee reasoned: "I think chiropractic is scientific. The manipulations were forceful, and I heard my back crack." Because he felt and heard the physical effects of manipulations, this individual concluded that chiropractic should be classified as science rather than New Age spirituality.

Several respondents evaluated chiropractic as more effective than biomedicine. Individuals who indicated that they disliked going to doctors, or could not afford them, reported seeing a chiropractor "from time to time" - often one or more times per week - for adjustments, whether or not anything seemed "out of place." Asked to "circle any/all of the following from which you might seek aid if you ever need another condition healed: PRAYER, PHYSICIAN OR OTHER HEALTH-CARE PROFESSIONAL, ALTERNATIVE MEDICAL OR SPIRITUAL REMEDIES (see question 14)-please specify which: ," one respondent circled "prayer" and, tellingly, wrote in "my faithful chiropractor."127 Another respondent expressed a broader willingness to experiment with healing alternatives. She circled having tried chiropractic, massage, naturopathy, acupuncture, herbal, and homeopathy, and specified that "all my healing has come from alternative medicine." At the conclusion of the conference, this woman-having experienced alternatives as therapeutically efficacious-indicated her intention to continue combining prayer, biomedicine, and alternative remedies.

\footnotetext{
${ }^{127}$ The quotation is from question six of the post-conference survey; question fourteen of the post-conference survey provides the identical list of alternatives given by question nine of the pre-conference survey.
} 
Christians interviewed felt motivated to reclassify chiropractic as legitimate because they found that they could get something from chiropractors that they were not getting from their medical doctors or churches - and that most did not feel authorized to seek from techniques coded as New Age. Chiropractic promises to heal diseases and to meet felt needs of people in pain-for someone to listen, validate the legitimacy of their complaints, do something to provide relief, and restore a lost sense of meaning, control, and hope. ${ }^{128}$ Spending up to an hour with patients at each of frequent appointments, chiropractors do not demand a physiological cause in order to take pain seriously-the physical reality of which they validate with physical manipulations. ${ }^{129}$ Chiropractic fills the vacuum of meaning with an appealing explanation of pain: something is simply out of adjustment, and balance can be restored without making either the hurting person or God morally culpable. The chiropractor takes control of the situation by doing something actively and by empowering patients to do something, even if it is as simple as maintaining better posture. Patients, who may have heard clergy defer hope of relief to the afterlife or physicians eradicate hope, gain reassurance that the situation will improve through ongoing adjustments. The intense loyalty and defensiveness toward their chiropractors exhibited by several Christians interviewed, through comments such as "I love my chiropractor!" suggest the tenacity with which they want to protect their means of meeting religious needs to identify causes, attribute blame, and find meaning. More than a medical service, chiropractic functions to explain life's struggles, cope with present stressors, and anticipate the future with hope.

Goaded by an urgent need for pain relief yet uneasy about becoming tainted by New Age spirituality, Christians rationalize their therapeutic experimentation. The vagueness with which chiropractors typically explain adjustments allows Christian patients to hear what they want to hear, finessing their understandings of chiropractic philosophy to line up with their theologies. One interviewee after another - who felt no need to comment on the religious beliefs of their medical doctors-volunteered that their chiropractors were Christians. One individual

\footnotetext{
${ }^{128}$ Cherkin and MacCornack, "Patient Evaluations," 351; Robert Kane, Donna Olson, Craig Leymaster, F. Ross Woolley, and F. David Fisher, "Manipulating the Patient: A Comparison of the Effectiveness of Physician and Chıropractor Care," Lancet 1 (1974): 1335-36.

${ }^{129}$ Ted J. Kaptchuk and David M. Eisenberg, "Chiropractic Origins, Controversies, and Contributions," Archives of Internal Medicine 158, no. 20 (November 9, 1998): 2215; White and Skipper, "Chiropractic Physician," 305. The sociologist John Naisbitt, in Megatrends . Ten New Directions Transforming Our Llves (New York: Warner Books, 1982), 48, helps to explain the appeal of chiropractic by observing that the "escalation of high technology within a society creates a compensatory need for "high touch."' As the historian J. Stuart Moore argues, in Chiropractic in America, 141, chiropractors win a loyal clientele in part because of their willingness to spend time "touching and listening, validating the often ambiguous pain associated with back ailments."
} 
had taken extensive notes on her chiropractor's citations of Bible verses, encouragements to go to a "Bible believing church," and claims that he only referred patients to other Christian practitioners. She interpreted his frequent references to unblocking "nerve energy" as denoting "medical help" that restored the body to how "God has set it up." Another interviewee insisted that "chiropractic is purely mechanical," but also felt compelled to note that "most of the chiropractors I know are Christians" and that "there is a relationship between Christianity and chiropractic." This individual reasoned that the "essence of righteousness" is to stand "upright" or "vertical" before God rather than "lean" on one's own understanding (Proverbs 3:5) - something made possible when a chiropractor restores the body's "perfect balance and alignment." Another interviewee admitted that she did not have a "good feeling" about going to a chiropractor. Faced with pain that her doctor had neither alleviated nor taken seriously, she finally tried chiropractic. She justified her decision on the grounds that "everybody at church goes," an influential member of her church was a chiropractor, and all her Christian friends were "talking about how great they were" and saying "you should go." This individual reasoned that if chiropractic was un-Christian, so many Christians would not be promoting chiropractic. Ironically, many of the same Christians who insist that "so many chiropractors are Christians!" do not believe that all people who call themselves Christians really are. But chiropractors are made less instead of more responsible for proving their orthodoxy because of the services they offer.

Not only lay Christians but also nationally influential Christian leaders typically insist on chiropractic's legitimacy when they have themselves experienced pain relief. Leaders of the Charismatic group that was studied occasionally make anecdotal references to their visits to chiropractors within sermons on divine healing. One nationally prominent pastor indicated in an interview with the author that she has consulted a chiropractor "for many years." She reported seeing her chiropractor about once every three weeks, and-having grown frustrated by repeated failures to experience relief of a longstanding physical complaint through divine healing - she had recently added more frequent biofeedback treatments from an herbalist whom her chiropractor recommended. At one point referring to chiropractic as a category of "medical stuff," she subsequently admitted to not liking the "idea of medicine, so I thought I would take an alternative route and it seems to be working really, really well for me." It seems unlikely that this individual or any of the other evangelical and Charismatic Christians interviewed - many of whom explicitly condemned New Age spiritualityunderstood the harmonial premises of chiropractic philosophy or envisioned themselves as participating in a metaphysical religious practice. Indeed, in the world of lived religion, practitioner and patient often invest the same therapeutic session with contrasting meanings. This Christian leader selected 
chiropractic because it was both like and unlike medicine and, especially, because it worked for her. ${ }^{130}$ Although she continued to endorse prayer for healing, it seems that a theological shift occurred: expectations of the accessibility of divine healing diminished as she refocused her efforts to pursue alternative therapies.

\section{ConClusion}

After decades of mutual suspicion, chiropractic and Christianity have been reinterpreted as complementary rather than competitive. This history of interconnection substantiates Catherine Albanese's avowedly "impressionistic" suggestion that evangelicals today constitute the "backbone" of American metaphysical religion, a backbone that has in recent years received regular chiropractic adjustments. ${ }^{131}$ Contrary to secularization theories that posit the growing privatization of religious experience, the recent heyday of chiropractic reflects a larger move of religiously-infused, combinative practices into the political arena as individuals insist publicly on their right to use-and be reimbursed for using - the diverse array of therapies they have intermingled all along. As historian Robert Johnston argues of alternative healing generally, chiropractic has a remarkable capacity to combine ideologies from the political left and right, such as anti-professionalism and individual responsibility, thereby transcending political — and one might add religious - categories to win a broad spectrum of defenders. ${ }^{132}$ In an era in which the political power of evangelical and alternative healing constituencies is of great media interest, largely unrecognized intersections of these communities with each other and with orthodox medicine merit further consideration. The need for scholarly attention is particularly acute given political scientist Fred Frohock's suggestion that American liberal democracy may prove ill-equipped to develop neutral procedures for regulating healing practices that blend metaphysical, evangelical, and scientific assumptions about the nature of reality. ${ }^{133}$

\footnotetext{
${ }^{130}$ Having classified pain as morally evil, Charismatics tend to classify practices as bad or good depending upon whether they are perceived as exacerbating or alleviating pain. Interestingly, Charismatics are quick to denounce other "nature cures," such as freemasonry (Albanese, Nature Religion, 56, 186; Whorton, Nature Cures, xii), that they blame for causing sickness; see, for example, Barbara Cassada, Unto Death: Freemasonry ... Freedom in Christ or Bondage to Lucifer? (Maryville, Tenn.: Tome Publishing, 1998), 8, in which Cassada lists diseases that she claims occur more frequently among Masonic families-and explains that it was this discovery that made her aware of freemasonry's non-Christian religious beliefs.

${ }^{131}$ Albanese, Republic of Mind and Spirit, 510.

${ }^{132}$ Johnston, Politics of Healing, 4; see also Michael S. Goldstein, Alternative Health Care: Medictne, Miracle, or Mirage? (Philadelphia: Temple University Press, 1999), 10-11.

${ }^{133}$ Fred M. Frohock, Healing Powers: Alternative Medicine, Sptritual Communities, and the State (Chicago: University of Chicago Press, 1992), vii.
} 
The case of chiropractic's dramatic readjustment from the fringes to the center of American healthcare practices raises questions about the future cultural identities of other health-promotion and healing alternatives that currently occupy a more marginal cultural space. Increasingly popular practices such as yoga, Pilates, tai chi chuan, homeopathy, aromatherapy, acupuncture, Therapeutic Touch, shiatsu, and Reiki, like chiropractic, developed out of vitalistic belief frameworks that envision such techniques as means of achieving harmony with universal life-force energy. ${ }^{134}$ Forty years ago, few Americans were intimately familiar with any of these techniques; today, such practices have found a growing niche in Walmart fitness and pharmacy aisles, YMCAs, public school physical education classes, nursing schools, hospitals, and some Christian churches. Nevertheless, such techniques remain controversial, presented by some as non-religious wellness activities, and by others-particularly members of conservative Christian subcultures - as religious practices antithetical to Christianity. ${ }^{135}$ Based on chiropractic's historical trajectory and current debates over the meanings of other alternatives, observers might soon expect to see many such practices culturally reconstituted as at once spiritual, scientific, and comfortably accommodated within conservative Christianity.

\footnotetext{
${ }^{134}$ Whorton, Nature Cures, 277; Albanese, Republic of Mind and Spirit, 508.

${ }^{135}$ Illustrative of current debates over the meanings of alternative practices are popular publications like: Alexandra Alter, "Yoga Stretches Traditional Christian Boundaries," Religion News Service (2003), available at http://www.hvk.org/articles/0703/169.html (accessed March 10, 2009); Agnieszka Tennant, "Yes to Yoga," Christianity Today Magazine (May 19, 2005), available at $\mathrm{http} / / \mathrm{www} . c t$ library.com/ct/2005/mayweb-only/42.0b.html (accessed March 10, 2009); Holly Vicente Robaina, "Take a Pass on Yoga," Christianity Today Magazine ( January 17, 2007), available at http://www.ctlibrary.com/ct/2005/juneweb-only/123-22.0.html (accessed March 10, 2009); Edzard Ernst, "Is Reiki Anti-Church and Is It Harmful?" Pulse 63, no. 37 (2003): 96; Michael Fuchs, "Reiki Is Not Religion," Massage Magazine 121 (2006): 34-35; Susan Anthony Salladay, "Should Christians Use Therapeutic Touch?" Christian Bioethics 8, no. 1 (2002): 25-42; W. Michael Westbrook, Baptizing Alternative Medicine: A Guide for the Curious but Cautious Christian (New York: Writer's Club Press, 2003).
} 


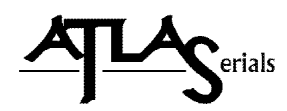

Copyright and Use:

As an ATLAS user, you may print, download, or send articles for individual use according to fair use as defined by U.S. and international copyright law and as otherwise authorized under your respective ATLAS subscriber agreement.

No content may be copied or emailed to multiple sites or publicly posted without the copyright holder(s)' express written permission. Any use, decompiling, reproduction, or distribution of this journal in excess of fair use provisions may be a violation of copyright law.

This journal is made available to you through the ATLAS collection with permission from the copyright holder(s). The copyright holder for an entire issue of a journal typically is the journal owner, who also may own the copyright in each article. However, for certain articles, the author of the article may maintain the copyright in the article. Please contact the copyright holder(s) to request permission to use an article or specific work for any use not covered by the fair use provisions of the copyright laws or covered by your respective ATLAS subscriber agreement. For information regarding the copyright holder(s), please refer to the copyright information in the journal, if available, or contact ATLA to request contact information for the copyright holder(s).

About ATLAS:

The ATLA Serials (ATLAS $®)$ collection contains electronic versions of previously published religion and theology journals reproduced with permission. The ATLAS collection is owned and managed by the American Theological Library Association (ATLA) and received initial funding from Lilly Endowment Inc.

The design and final form of this electronic document is the property of the American Theological Library Association. 